\title{
Ortaöğretimde Çalışan Öğretmenlerin Eleştirel Düşünme Becerileri ile Okul Sağlığı Algıları Arasındaki İlişki
}

\author{
DOI: $10.26466 /$ opus.569567
}

\author{
Dilşad Bakır* - Erdal Toprakçı* - Esen Altunay*** \\ * İngilizce Öğretmeni, MEB İzmir Karabağlar Cumhuriyet Anadolu Lisesi / İzmir / Türkiye \\ E-Posta: dilsad 26 @hotmail.com ORCID: 0000-0002-0041-6458 \\ ** Prof. Dr., Ege Üniversitesi, Eğitim Fakültesi / İzmir/ Türkiye \\ E-Posta: erdal.toprakci@ege.edu.tr ORCID: 0000-0001-9552-9094 \\ *** Doç. Dr., Ege Üniversitesi, Edebiyat Fakültesi / İzmir/ Türkiye \\ E-Posta: esenaltunay@yahoo.com \\ ORCID: $\underline{0000-0001-8200-8871}$
}

Öz

Araştırmanın amacı ortaöğretimde çalışan öğretmenlerin eleştirel düşünme becerileri ile okul sağlı̆̆ı alg̨ları arasındaki ilişkiyi incelemek ve bulgular doğrultusunda öneriler geliştirmektir. Araştırmanın yöntemi ilişkisel taramadır. Araştırmanın evrenini 2017-2018 eğitim-öğretim yılında İzmir ilindeki devlet liselerinde görev yapan öğretmenler oluşturmaktadır. Oranlı küme örnekleme yöntemi kullanılarak belirlenen çalışmanın örneklemini İzmir ili Buca, Çiğgli, Gaziemir, Karabağlar, Karşıyaka ve Konak ilçelerindeki devlet liselerinde çalışan 897 öğretmen oluşturmaktadır. Araştırmaya 724 öğretmen katılmıştır. Araştırmanın sonuçlarına göre ortaöğretim öğretmenlerinin eleştirel düşünme becerileri toplam puanı cinsiyete ve okullarındaki öğretmen sayısına göre anlamlı düzeyde farklılık göstermektedir. Ortaöğretim öğretmenlerinin eleştirel düşünme becerileri alt boyutları puanları ve okul sağhlğı algıları puanları cinsiyete, branşa, okullarındaki öğretmen sayısı ve öğrenci sayısına göre anlamlı düzeyde farklilı göstermektedir. Ortaöğretim öğretmenlerinin eleştirel düşünme becerileri toplam puanlar ve alt boyutları puanları ile örgüt sağhlğı alt boyutları arasındaki ilişkinin olumlu yönde düşük düzeyde bir ilişki olduğu ve eleştirel düşünme becerileri alt boyutlarının örgütsel sağhlk alt boyutları üzerinde anlamlı bir açıklayıcı olduğu görülmüştür

Anahtar Kelimeler: Örgüt sağhlğ l; Okul sağllğgl; Eleştirel düşünme becerileri; Ortaöğretim öğretmenleri 


\title{
The Relationship between Secondary Schools Teachers' Critical Thinking Skills and School Health Perceptions
}

\begin{abstract}
The aim of the research was to examine the relationship between secondary schools teachers' critical thinking skills and school health perceptions and to develop suggestions in the direction of findings This study was designed as a relational survey model. The universe of the research was composed of the teachers working in the state secondary schools in Izmir in the 2017-2018 academic year. The sample of the study determined by the proportional cluster sampling method constituted 897 teachers working in state secondary schools in the districts of Buca, Çĭ̆li, Gaziemir, Karabağlar, Karşıyaka and Konak in Izmir but 724 teachers participated in the research. According to the results of the research the total scores of secondary school teachers' critical thinking skills showed a significant difference according to their gender and the number of teachers in their schools. The subscale scores of secondary school teachers' critical thinking skills showed significant differences according to their gender, branches, the number of teachers and students in their schools. The school health perception scores of secondary school teachers showed a significant difference according to their gender, branches, the number of teachers and students in their school. It was seen that there was a positively low correlation between secondary school teachers' critical thinking skills total and subscale scores and organizational health subscales in addition critical thinking skills subscales explained organizational health subscales significantly.
\end{abstract}

Keywords: Organizational health, School health, Critical thinking skills, Secondary school teachers. 


\section{Giriş}

Yaşamın hemen her alanındaki hızlı değişim eğitim sistemlerinden beklentileri de artırmıştır. Yeni koşullara uyum sağlayan, bilgiyi edinen değil, bilgiyi yapılandıran, üreten, eleştirel düşünebilen, yaratıcı, sorun çözebilen bireylerin yetişeceği yerler de okullar olarak görülmektedir. Bu görev, uygulanan eğitim programlarının beklentileri karşılayabilecek nitelikte olmasını, günün koşullarına uygun olarak geliştirilmesini ve okullardaki öğretme-öğrenme süreçlerinin yeniden kurgulanmasını gerekli kılmaktadır (Sağlam, Vural ve Adıgüzel, 2007). Eğitimdeki değişimin başlangıç yerinin okullar olması, okulların buna hazır olup olmamak bakımından ne kadar sağlıklı olduklarını özellikle üzerinde durulması gereken bir konu haline getirmektedir.

Okulların, eğitim-öğretim yönünden giderek etkisizleştiği, öğrencinin, çevrenin, velinin, iş dünyasının beklentilerini karşılamaktan uzaklaştı̆̆ eğitim öğretimde kalite ve niteliğin düşmekte olduğu sıklıkla dile getirilen yakınmalar arasındadır. Söz konusu yakınmaların bilimsel araştırmalarla test edilmesi, sorunların doğru saptanmasının ve sorunları gidermeye dönük çözüm önerilerinin bulunabilmesinin ön şartıdır (Şişman, 2002: 209). Bu bağlamda incelenmesi gereken konulardan biri de bir örgüt olarak okulların sağlığıdır. Sağlık kavramı, biyolojik açıdan canlılarla ilgili bir kavram olup bir canlının hastalıklardan uzak olmasını, gelişimini ve yaşamını düzenli bir şekilde sürdürmesini ifade eder (Şişman, 2007). Hoy ve Feldman'a (1987) göre, sağlıklı okul; teknik, yönetimsel ve kurumsal seviyelerini uyumlu bir bütün haline getirmiş, ihtiyaçlarını başarıyla karşılayan diştan gelen yıkıcı etkilerle baş eden ve enerjisini kendi misyonuna yönlendiren okul olarak (Akbaba, 2001) tanımlanabilir. Kurum açısından bakıldığında sağlıklı bir okul çevresiyle iyi ilişkiler içinde olan, bu çevre tarafından meşrulaştırılan ve bu çevreden destek alan okuldur. Okulun yönetimi açısından bakıldığında, sağlıklı okul; okula kaynak sağlayan, bu kaynakları dağıtan, okulun amaçlarının gerçekleştirebilmesi için çalışanlarına yön veren ve rehberlik edebilen bir okul müdürünün bulunduğu okuldur. Öğretmen açısından bakıldığında, öğrenme ve öğretmenin en verimli şekilde yürütüldüğü, akademik başarının ön plana çıtığı, öğrenmenin her şeyden önce geldiği bir anlayışın egemen olduğu bir ortam anlamına gelmektedir (Akbaba, 2001). Eğitim sistemi ve toplum açısından, 
okulların sağlıklı olmasının hayati bir önem taşıdığı söylenebilir çünkü birer sosyal sistem olarak okulların girdi, süreç ve çıktı döngüsünün her noktasında insanlar bulunmaktadır. Bundan dolayı örgüt sağlığının diğer örgütler kadar eğitim örgütleri için de önem taşıdığı söylenebilir. Eğitim örgütlerinin gelecek yüzyılın ihtiyaçlarına cevap verebilmesi ancak sağlıklı olmasıyla mümkün olabilir. Okulların sağlık düzeylerinin bilinmesi varlıklarını sürdürebilmeleri ve buna göre gelecek için plan yapmalarına katkı sağlayabilir.

Öğrenci, öğretmen, yönetici ve diğer ilgilileri açısından okullar sağlıklı ve sağlıksız olarak kavramsallaştııılmıştır. Geleneklere bağlılığın esas olduğu, yenilikçiliğin olmadığı, başarının ciddiye alınmadığı, başarılı öğretmenlerin okul tarafından tehdit unsuru olarak algılandığı, öğretmen ve yöneticilerin toplum ve veli baskısıyla karşılaştı̆̆ı, okul yöneticilerinin öğretmen ve öğrencilere çok destekleyici olmadığı ve öğretmenlerin de birbirlerine ve mesleğine karşı ilgisiz olduğu okullar sağlıksız okullar olarak tanımlanmıştır (Hoy, Tarter ve Kottkamp, 1991).

Okulun sağlıklı olması için onu oluşturan bireylerin de bazı özelliklere sahip olması gerekir. Bu özelliklerin en başında eleştirel düşünme becerileri gelmektedir. Düşünmeyi bilen, neden sonuç ilişkisi kurabilen, çevresindeki olay ve olguları sorgulayabilen, gelişime açık, bilime ve bilimsel düşünceye değer veren, analitik düşünme ve problem çözme becerisine sahip bireylerin eleştirel düşünme becerisine sahip olduğu düşünüldügünde bu tip bireylerin oluşturduğu okullarda üretken, yaratıcı ve demokratik bir ortam oluşacaktır. Her birey taşıdığg sorumluluğun bilincinde olarak görevini yerine getirecektir.

Milli Ĕ̆itim Bakanlığı bünyesinde, eğitimde kalitenin artırılmasına yönelik yenilikçi ve araştırıcılığı temel alan yeni ve yapılandırmacı eğitim programlarının (Şişman ve Taşdemir, 2008) yürütülebilmesi için öğretmenler ve okul yöneticilerinin içinde yer aldığı sağlıklı okullara sahip olmak önkoşul olarak görülmektedir. Yapılandırmacılıkta öğrenenlerin bilgiyi hatırlamasından öte bilimsel araştırmacı, problem çözücü, eleştirel düşünen, özerk düşünen bireyler olmasına yönelik hedefler vardır (Yurdakul, 2008). Bu bağlamda geleceğin eğitim de dahil bütün örgütlerinde çalışacak kişilerin bugünün öğrencileri olarak eleştirel düşünceye kavuşturulması sağlıklı toplum için bir anahtar rolü oynayabilecektir. 
Okul sağlığı ile ilgili çalışmalar incelendiğinde, ilköğretim öğretmenlerinin iş motivasyonları (Güçlü, Recepoğlu ve Kılınç, 2014; Ebcim, 2012); okul yöneticilerinin kriz yönetim tutumları (Yıldız, 2014) ve ilköğretim okullarındaki okul kültürü (Özdemir, 2012) ile örgüt sağllğı arasındaki ilişkinin incelendiği tespit edilmiştir. Ayrıca örgüt sağlığı ile örgütsel yapının (Ordu, 2011), etik liderliğin (Taneri, 2011) ve ortaöğretim okullarındaki örgütsel vatandaşlık davranışlarının arasında bulunan ilişkinin ( $\mathrm{Bu}-$ luç, 2008) ve bürokrasinin örgütsel sağlık üzerine olan etkisinin (Akıl, 2005) araştırıldığı görülmektedir. Buna ek olarak okulların sağlığına ilişkin öğretmen algılarının da (Kesik ve Balcı, 2015; Recepoğlu ve Özdemir, 2014; Gürkan, 2006); araştırıldığ1 tespit edilmiştir. Yurt dışında yapılan araştırmaların bazıları incelendiğinde ise okul sağlığı ile öğretmen bağl1lığı (Tsui ve Cheng, 1999); okul sağlığı ile öğretmenlerin yeterlilik duygusu arasındaki ilişkinin (Hoy ve Woolfolk, 1993) araştırıldığı görülmektedir.

Eleştirel düşünme ile ilgili yapılan araştırmalar incelendiğinde, öğretmen adaylarının eleştirel düşünme tutumları ile algıladıkları mesleki etik ilkelerinin (Sakar, 2015) ve lise öğretmenlerinin eleştirel düşünme eğilimleri ile duygusal zekâ düzeyleri arasındaki ilişkinin (Erdem, İlğan ve Çelik, 2013) incelendiği tespit edilmiştir. Ayrıca okul yöneticilerinin eleştirel düşünme eğilimleri ile karar verme stratejileri (Tuncer, 2013) ve öğretmen adaylarının eleştirel düşünme tutumları ile denetim odakları arasındaki ilişkinin (Saracaloğlu ve Yılmaz, 2011) araştırıldığı görülmektedir. Buna ek olarak yüksek eleştirel düşünme eğilimlerine sahip öğrencilerle düşük eleştirel düşünme eğilimlerine sahip öğrenciler arasındaki akademik başarı farkının (Akbıyık ve Seferoğlu, 2006) ve fizik öğretmenlerinin düzenledikleri etkinliklerdeki eleştirel düşünmenin yerinin (Şengül ve Üstündağ, 2009) çalışıldığı tespit edilmiştir. Ayrıca öğretmen adaylarının (Beşoluk ve Önder, 2010; Aybek, 2006) ve sınıf öğretmenlerinin eleştirel düşünme becerileri (Palavan, Gemalmaz ve Kurtoğlu, 2015) ve ilköğretim okullarındaki yöneticilerin eleştirel düşünme gücünün (Ayaz, 2012) araştırıldığı görülmektedir. Yurt dışında yapılan eleştirel düşünme çalışmalarının bazıları incelendiğinde ise eleştirel düşünme engellerine öğretmenlerin bakışının (Aliakbaria ve Sadeghdaghighib, 2012) ve öğrencilere göre öğretmenlerin eleştirel düşünmeye bakışı ve bunun yükseköğretime etkisinin (Choy ve Cheah, 2009) araştırıldığı görülmektedir. 
Yurt içinde ve yurt dışında yapılan çalışmalara göre örgüt sağlığının daha çok ilköğretim okullarında (Akıl, 2005; Hoy ve Woolfolk, 1993; Ordu, 2011), eleştirel düşünme becerilerinin ise daha çok üniversite çatısı altında eğitim-öğretim gören öğrenciler (Korkmaz, 2009b) veya öğretmen adayları (Beşoluk ve Önder, 2010) üzerinde çalışıldığı görülmektedir. Bu bağlamda ortaöğretimde çalışan öğretmenlerin eleştirel düşünme becerileri ile okul sağlığına ilişkin algıları arasındaki ilişkinin şimdiye dek incelenmediği tespit edilmiştir. Bu çalışmanın amac1; ortaöğretimde çalışan öğretmenlerin eleştirel düşünme becerileri ile okul sağlığı algıları arasındaki ilişkiyi incelemek ve bulgular doğrultusunda öneriler geliştirmektir. Okulların sağlı̆̆ının öğretmen algısı üzerinden anlaşılarak ve öğretmenlerin eleştirel düşünme becerilerinin onlara sorularak öğrenilmesi temelinde araştırmanın ortaöğretim öğretmenlerinin okul sağlığı algıları ile eleştirel düşünme becerileri arasındaki ilişkinin anlaşılması açısından alana katkı sağlayabileceği umulmaktadır.

\section{Yöntem}

Araştırmada devlet liselerinde görev yapan öğretmenlerin okul sağlı̆̆ algısı ve eleştirel düşünme becerileri arasındaki ilişki incelendiği için ilişkisel tarama modeli kullanılmıştır.

Araştırmanın evrenini İzmir ilindeki devlet liselerinde görev yapan öğretmenler oluşturmaktadır. Çalışmanın örneklemi ise İzmir ili Buca, Çiğli, Gaziemir, Karabağlar, Karşıyaka ve Konak ilçelerindeki devlet liselerinde çalışan 897 öğretmendir. Oranlı küme örnekleme yöntemi ile her ilçedeki toplam ortaöğretim öğretmen sayısının altı ilçede görev yapan toplam ortaöğretim öğretmeni sayısına olan oranı belirlenmiştir. İkinci adımda her ilçedeki devlet liselerinde çalışan öğretmen sayısının altı ilçedeki devlet liselerinde çalışan toplam öğretmen sayısına olan oranına göre yüzdesi alınarak hedeflenen örneklem sayısı belirlenmiştir. Her ilçe için aynı hesaplama yapılarak ölçek formlarının dağıtılması için gerekli olan örnekleme (897 öğretmen) ulaşılmıştır. Dağıtılan ölçeklerden 775 ölçek geri dönmüştür. Kontrol edilen ve eksik cevaplanan ölçekler ayıklandıktan sonra 724 tane ölçeğin kullanılabilir olduğu görülmüştür. Buna göre ölçeklerin geri dönüş oranı \%67'dir. Örneklemin sosyo-demografik dağılımları Tablo 1'de gösterilmektedir. 
Tablo 1. Örneklemin Bireysel Özelliklere Göre Dă̆ılımı

\begin{tabular}{llll}
\hline Değişken & & $\mathbf{N}$ & $\mathbf{\%}$ \\
\hline Cinsiyet & Kadın & 451 & 62,3 \\
& Erkek & 273 & 37,7 \\
\hline Branş & Sözel Alan & 330 & 45,6 \\
& Sayısal Alan & 189 & 26,1 \\
& Uygulamalı Alan & 48 & 6,6 \\
& Meslek Dersi & 157 & 21,7 \\
\hline Öğretmen Sayısı & $0-25$ & 36 & 5,0 \\
& $26-50$ & 174 & 24,0 \\
& $51-75$ & 279 & 38,5 \\
& $76-100$ & 148 & 20,4 \\
& $101-125$ & 55 & 7,6 \\
& $126-150$ & 32 & 4,4 \\
\hline Öğrenci Sayısı & $0-300$ & 21 & 2,9 \\
& $301-600$ & 112 & 15,5 \\
& $601-900$ & 296 & 40,9 \\
& $901-1200$ & 138 & 19,1 \\
& $1201-1500$ & 110 & 15,2 \\
& $1501-1800$ & 42 & 5,8 \\
\hline Toplam & & 724 & 100 \\
\hline
\end{tabular}

Tablo 1'deki örneklemin bireysel özelliklere göre dağılımı incelendiğinde, katılanların çoğunluğunun kadın ( $n=451, \% 62,3)$, sözel dersleri veren $(\mathrm{n}=330, \% 45,6), 51-75$ arası öğretmenin çalıştığ1 $(\mathrm{n}=279, \% 38,5)$ ve 601900 öğrencinin $(n=296, \% 40,9)$ eğitim-öğretim gördüğü okullarda çalışan kişilerden oluştuğu görülmektedir.

Ortaöğretimde çalışan öğretmenlerin eleştirel düşünme becerileri ile okul sağ lığı algıları arasındaki ilişkiyi incelemek için devlet liselerinde çalışan öğretmenlerden öncelikle kişisel bilgileri istenmiş daha sonra ise “Örgüt Sağllğı" ve "Eleştirel Düşünme” ölçekleri kullanılarak söz konusu öğretmenlerin değişkenlere ilişkin görüşleri belirlenmeye çalışılmıştır.

“Örgüt Sağlı̆̆ 1 Ölçeği" Akbaba (1997) tarafından geliştirilmiştir. Ölçek dörtlü likert tipindedir ve "Her Zaman", "Ara Sıra”, “Nadiren”, "Hiçbir Zaman" olarak puanlanmaktadır. Ölçeğin boyutları; örgütsel liderlik, örgütsel bütünlük, çevresel etkileşim, örgütsel kimlik ve örgütsel üründür. 53 maddeden oluşan Örgüt sağlığı ölçeğinin güvenirlik katsayısı (Croanbach Alpha) .95'tir. Örgüt sağllğı ölçeği alt boyutlarının güvenirlik 
katsayıları (Croanbach Alpha); “Örgütsel liderlik .93”, "Çevresel etkileşim .80", “Örgütsel bütünlük .84”, “Örgütsel kimlik .74”, “Örgütsel ürün .72” olarak hesaplanmıştır (Akbaba, 1997). Bu araştırmada hesaplanan örgüt sağlı̆̆ı ölçeği güvenirlik katsayısı (Croanbach Alpha) .97; alt boyutların güvenirlik katsayıları ise (Croanbach Alpha) “Örgütsel liderlik .95”, “Çevresel etkileşim .85”, “Örgütsel bütünlük .80”, “Örgütsel kimlik .84”, “Örgütsel ürün .86" olarak hesaplanmıştır. Eleştirel Düşünme Ölçeği, öğrencilerin "eleştirel düşünme düzeylerini" belirlemek amacıyla Derelioğlu (2004) tarafından geliştirilmiştir. Derelioğlu'nun eleştirel düşünme ölçeği 55 sorudan oluşmaktadır ve 10 alt boyutu olan 5' li Likert tipinde bir ölçektir. Bunlar "Hemen hiç bir zaman", "Nadiren", "Bazen", "Çoğu zaman" ve "Hemen her zaman" şeklindedir. Ölçeğin güvenirlik katsayısı (Croanbach Alpha) .93 olarak hesaplanmıştır (Derelioğlu, 2004). Derelioğlu tarafından "Eleştirel Düşünme" ölçeğinin alt boyutlarının ayrı ayrı güvenirliğini belirlemek için Cronbach $\alpha$ katsayılarının hesaplanmadığ tespit edilmiştir. $\mathrm{Bu}$ araştırmada hesaplanan eleştirel düşünme ölçeğinin güvenirlik katsayısı (Croanbach Alpha) .93; alt boyutların güvenirlik katsayıları ise (Croanbach Alpha) "Düşünceleri düzene koyma .79", "Bilgileri sorgulama .77", “Duygu, düşünce ve değerleri farkındalık .77," "Problem çözme .70”, “Açı fikirlilik ve hoşgörü .69”, "Eşduyum (düşüncede esneklik) .54", “Kendini geliştirme .76", “Eleştiriye açıklık .38”, "Fikirlerde ayrıntıya dikkat .35", "Akılcı düşünme .36" olarak hesaplanmıştır.

Araştırmanın verileri çözümlenirken SPSS 21.00 istatistik paket programından yararlanılmıştır. Problem ve alt problemlerin özelliği dikkate alınarak normal dağılıma sahip değişkenlerde farkın belirlenmesinde ise $t$ testi ve varyans analizi ve farklılığın kaynağını bulmak için Sidak testi (varyanslar eşit, üç ve üçten fazla grup olduğu için), değişkenlerin normal dağılıma sahip olmadığı değişkenlerde Kruskal Wallis H testi ve farkın kaynağını bulmak için Mann Whitney U testi, ortaöğretim öğretmenlerinin okul sağlığı algıları ve eleştirel düşünme becerileri arasındaki ilişkiyi belirlemek için korelasyon analizi ve çoklu regresyon analizi yapılmıştır. 


\section{Bulgular ve Yorum}

Öğretmenlerin eleştirel düşünme beceri düzeyleri ile bu düzeylerin bireysel özelliklere (cinsiyet, branş, okullarındaki öğretmen ve öğrenci sayısi) göre farklılı̆̆

Bu alt problem doğrultusunda ortaöğretim öğretmenlerinin eleştirel düşünme becerileri düzeyleri itibariyle Tablo 2' de verilmiştir:

Tablo 2. Ortaöğretimde çalışan öğretmenlerin eleştirel düşünme becerileri

\begin{tabular}{lccl}
\hline Eleştirel Düşünme & SS & $\overline{\mathbf{X}}$ & SKPA Anlami* \\
\hline Düşünceleri düzene koyma &, 66 & 3,84 & Çoğu zaman \\
Bilgileri sorgulama &, 56 & 4,06 & Çoğu zaman \\
Duygu, düşünce, değerleri farkındalık &, 60 & 4,06 & Çoğu zaman \\
Problem çözme &, 59 & 3,81 & Çoğu zaman \\
Açık fikirlilik ve hoşgörü &, 56 & 4,20 & Her zaman \\
Eşduyum (Düşüncede esneklik) &, 54 & 3,57 & Çoğu zaman \\
Kendini geliştirme &, 62 & 4,15 & Çoğu zaman \\
Eleştiriye açıklık &, 54 & 3,62 & Çoğu zaman \\
Fikirlerde ayrintıya dikkat &, 67 & 3,82 & Çoğu zaman \\
Akılcı düşünme &, 69 & 4,04 & Çoğu zaman \\
Eleştirel Düşünme Toplam &, 47 & 3,85 & Çoğu zaman \\
\hline
\end{tabular}

*Seçeneklere Göre Kodlanan Puan Aralı̆̆

Ortaöğretim öğretmenlerinin eleştirel düşünme becerileri puan ortalamaları incelendiğinde yüksek düzeyde olduğu sonucuna varılmaktadır. Alanyazındaki araştırmaların bulguları göz önüne alındığında benzer bulgulara rastlanmıştır. Şahin ve Gözütok (2013), öğretmenlerin eleştirel düşünmeyi destekleme davranışlarını gösterme düzeylerinin yüksek olduğu sonucuna ulaşmıştır. Tuncer'e (2013) göre okul yöneticilerinin eleştirel düşünme eğilimleri düşük düzeydedir. Buna rağmen alt boyutlarda en çok "açık fikirlilik" alt boyutunda eğilim yüksek çıkarken; en düşük eğilim "sistematiklik" alt boyutunda çıkmıştır. Buna ek olarak Saracaloğlu ve Yılmaz (2011) dış denetim odağına sahip öğretmenlerin eleştirel düşünme tutum puanlarının daha yüksek olduğunu tespit etmiştir. Korkmaz'a (2009a, 2009b) göre ise öğretmenlerin ve eğitim fakültesi öğrencile- 
rinin eleştirel düşünme eğilimleri orta düzeydedir. Benzer şekilde Özdemir'e (2003) göre üniversite öğrencilerinin eleştirel düşünme becerilerinin orta düzeyde olduğu tespit edilmiştir. Diğer taraftan Beşoluk ve Önder'e (2010) göre öğretmen adaylarının eleştirel düşünme becerilerinin genelde orta ve düşük düzeyde olduğu görülmüştür. Ayrıca Şengül ve Üstündağ’a (2009) göre fizik öğretmenlerinin düşük eleştirel düşünme düzeyine sahip olduğu ortaya çıkmıştır.

Alanyazın ve bu araştırmanın bulguları doğrultusunda ortaöğretim öğretmenlerinin eleştirel düşünme becerilerinin yüksek düzeyde çıkmasinın bir nedeni söz konusu öğretmenlerin kendi duygu ve düşüncelerini farkında olması ve kendilerini geliştirmeye istekli olmalarından kaynaklanabilir. Bunun yanı sıra ortaöğretim öğretmenlerinin değişen ve gelişen koşullarda doğup büyüyen genç neslin eğitim ve öğretimden sorumlu olduklarını farkında olmalarından dolayı açık fikirli ve bilimsel düşünmeye odaklı bireyler olarak kendilerini yetiştirmeye çalışmalarından kaynaklandığı söylenebilir.

\section{Cinsiyet}

Ortaöğretim öğretmenlerinin eleştirel düşünme becerilerinin cinsiyete göre anlamlı düzeyde farklılık gösterip göstermediğini tespit etmek için yapılan $\mathrm{t}$ testi sonucu elde edilen bulgular Tablo $3^{\prime}$ te verilmiştir.

Tablo 3 incelendiğinde, ortaöğretim öğretmenlerinin eleştirel düşünme becerileri toplam puan $(t=3,166 ; \mathrm{p}<0.05)$ cinsiyete göre anlamlı düzeyde farklılık göstermektedir. Buna ek olarak "Duygu, düşünce ve değerleri farkındalık" ( $t=3,709 ; p<0.05)$, "Açık fikirlilik ve hoşgörü" ( $t=4,100$; $\mathrm{p}<0.05)$, "Eşduyum (Düşüncede esneklik)" ( $\mathrm{t}=3,141 ; \mathrm{p}<0.05)$, "Kendini geliştirme" ( $t=3,576 ; p<0.05)$, "Eleştiriye açıklık" ( $t=3,269 ; \mathrm{p}<0.05)$ ve "Fikirlerde ayrıntıya dikkat" $(t=4,067 ; p<0.05)$ alt boyutları puanlarının cinsiyete göre anlamlı düzeyde farklılık gösterdiği tespit edilmiştir. Ortaöğretim öğretmenlerinin eleştirel düşünme toplam puanlarına bakıldığında kadınların puan ortalamalarının $(\overline{\mathbf{X}}=3,89)$ erkeklerin puan ortalamalarından $(\overline{\mathbf{X}}=3,78)$ daha yüksek olduğu görülmüştür. Anlamlı düzeyde farklılığın çıktığı alt boyutlar incelendiğinde kadınların puanlarının erkek öğretmenlerden yüksek olduğu görülmektedir. 
Tablo 3. Ortä̈ğretim öğretmenlerinin cinsiyete göre eleştirel düşünme becerilerine ilişkin yapılan t testi analizi sonuçları (Sadece Sidak testi sonucunda anlamlı farklılık gösterenler verilmiştir)

\begin{tabular}{|c|c|c|c|c|c|c|c|}
\hline Eleştirel Düşünme & Cinsiyet & $\mathbf{n}$ & $\overline{\mathbf{X}}$ & SS & Sd & $t$ & $\mathbf{P}$ \\
\hline \multirow[t]{2}{*}{ Duygu, düşünce, değerleri farkındalık } & Kadın & 411 & 4,13 & ,59 & \multirow{2}{*}{659} & \multirow{2}{*}{3,709} & \multirow{2}{*}{, 00 } \\
\hline & Erkek & 250 & 3,95 & 60 & & & \\
\hline \multirow[t]{2}{*}{ Açık fikirlilik ve hoşgörü } & Kadın & 414 & 4,27 &, 54 & \multirow{2}{*}{671} & \multirow{2}{*}{4,100} & \multirow{2}{*}{, 00} \\
\hline & Erkek & 259 & 4,09 &, 58 & & & \\
\hline \multirow[t]{2}{*}{ Eşduyum (Düşüncede esneklik) } & Kadın & 419 & 3,62 &, 52 & \multirow{2}{*}{674} & \multirow{2}{*}{3,141} & \multirow{2}{*}{,00 } \\
\hline & Erkek & 257 & 3,49 &, 56 & & & \\
\hline \multirow[t]{2}{*}{ Kendini geliştirme } & Kadın & 431 & 4,22 & 61 & \multirow{2}{*}{689} & \multirow{2}{*}{3,576} & \multirow[b]{2}{*}{00} \\
\hline & Erkek & 260 & 4,05 & 63 & & & \\
\hline \multirow[t]{2}{*}{ Eleştiriye açıklık } & Kadın & 422 & 3,67 &, 55 & \multirow{2}{*}{671} & \multirow{2}{*}{3,269} & \multirow{2}{*}{00} \\
\hline & Erkek & 251 & 3,53 &, 52 & & & \\
\hline \multirow[t]{2}{*}{ Fikirlerde ayrıntıya dikkat } & Kadın & 442 & 3,90 & 66 & \multirow{2}{*}{704} & \multirow{2}{*}{4,067} & \multirow{2}{*}{, 00} \\
\hline & Erkek & 264 & 3,69 & ,66 & & & \\
\hline \multirow[t]{2}{*}{ Eleştirel Düşünme Toplam } & Kadın & 451 & 3,89 & 46 & \multirow{2}{*}{722} & \multirow{2}{*}{3,166} & \multirow{2}{*}{, 00} \\
\hline & Erkek & 273 & 3,78 &, 48 & & & \\
\hline
\end{tabular}

Alanyazındaki araştırmaların bulguları incelendiğinde benzer bulgulara ulaşıldığ görülmektedir. Cinsiyete göre eleştirel düşünme becerilerinin kadınlarda erkeklere göre daha yüksek bulunduğu birçok araştırma sonucu ile desteklenmektedir (Ay ve Akgöl, 2008; Ayaz, 2012; Saracaloğlu ve Yılmaz, 2011; Beşoluk ve Önder, 2010). Diğer taraftan bazı araştırmalarda (Sakar, 2015; Varoğlu, 2014; Erdem, İlğan ve Çelik, 2013; Korkmaz; 2009a; Korkmaz, 2009b) cinsiyete göre katılımcılarda eleştirel düşünme eğilimlerinde anlamlı bir farklılık bulunmamıştır. Alanyazın ve bu araştırmanın bulguları doğrultusunda öğretmenlerin eleştirel düşünme becerilerinin kadınların lehine farklı çıkmasının bir nedeni kadınların çoğunun sahip olduğu duygusal olma, detaylara önem verme gibi karakteristik özelliklerden kaynaklanabilir. Ayrıca kadınların kendilerini ifade etme özelliğinin güçlü olmasının mesleklerine yansıdığı ve erkeklerin kendilerini daha katı gördüğü söylenebilir.

\section{Branş}

Ortaöğretim öğretmenlerinin eleştirel düşünme becerilerinin branşlarına göre anlamlı düzeyde farklılık gösterip göstermediğini tespit etmek için 
yapılan tek yönlü varyans testi sonucu elde edilen bulgular Tablo 4 'te verilmiştir.

Tablo 4 incelendiğinde, ortaöğretim öğretmenlerinin eleştirel düşünme becerileri toplam puanları branşlarına $(\mathrm{F}=1,466 ; \mathrm{p}>0.05)$ göre anlamlı düzeyde farklılık göstermemektedir. Ancak eleştirel düşünme becerilerinin alt boyutları incelendiğinde, "Açı fikirlilik ve hoşgörü" ( $F=3,466 ; p>0.05)$ ile "Fikirlerde ayrıntıya dikkat" ( $F=6,703 ; p>0.05)$ boyutlarında ortaöğretim öğretmenlerinin puanlarında branşlarına göre anlamlı düzeyde farklılık olduğu görülmektedir. Bundan dolayı farklılığın hangi gruplar arasında olduğunu tespit etmek için Sidak analizi yapılmıştır. Ortaöğretim öğretmenlerinin eleştirel düşünme becerilerinin branşa göre farkının kaynağını bulmak için yapılan Sidak analizinde; "Fikirlerde ayrıntıya dikkat" alt boyutunda sözel ve uygulamalı alan dersleri ile sözel ve meslek derslerini veren öğretmenler arasında anlamlı düzeyde farklılığın olduğu tespit edilmiştir. "Açık fikirlilik ve hoşgörü" alt boyutunda p değeri 0.05 'ten küçük çıkmasına rağmen farkın kaynağını bulmak için yapılan Sidak analizi sonucu hiçbir grup arasında anlamlı düzeyde farklılık çıkmamıştır. Buna ek olarak ortaöğretim öğretmenlerinin branşlarına göre eleştirel düşünme becerileri puan ortalamalarının "Açık fikirlilik ve hoşgörü" ( $\overline{\mathbf{X}}=$ $4,27)$ ve "Fikirlerde ayrıntıya dikkat" $(\overline{\mathbf{X}}==3,92)$ alt boyutlarında sözel dersleri veren öğretmenlerde diğer branşlarda derse giren öğretmenlere göre daha yüksek olduğu görülmüştür. Ortaöğretim öğretmenlerinin eleştirel düşünme becerileri toplam puanları branşlarına göre anlamlı düzeyde farklılık göstermezken; alt boyutların puanlarında anlamlı düzeyde farklılıklar olduğu görülmüştür.

Alanyazındaki araştırmalar incelendiğinde benzer bulgulara rastlanmıştır. Erdem, İlğan ve Çelik'e (2013) göre lise öğretmenlerinin eleştirel düşünme eğilimleri branş değişkenine göre anlamlı düzeyde farklılaşmaktadır. Diğer taraftan Korkmaz'a (2009a) göre branş değişkeni öğretmenlerin eleştirel düşünme eğilim ve düzeyleri üzerinde etkili değildir. Alanyazın ve bu araştırmanın bulguları doğrultusunda ortaöğretim öğretmenlerinin eleştirel düşünme becerilerinin sözel dersleri veren öğretmenlerde daha yüksek çıkmasının nedeni anlamlı farklılığın çıktığı eleştirel düşünme alt boyutlarının kapsadığı ayrıntılara önem verme ile açık fikirlilik ve hoşgörü gibi özelliklerin sözel alanlarda başarılı olan insanların karakteristik özelliklerine yakın olmasından kaynaklanabilir 
Tablo 4. Ortaöğretim öğretmenlerinin branşlarına göre eleştirel düşünme becerilerine ilişkin yapılan tek yönlü varyans testi analizi (Sadece Sidak testi sonucunda anlaml farklılık gösterenler verilmiştir)

\begin{tabular}{llllllll}
\hline $\begin{array}{l}\text { Eleştirel } \\
\text { Düşünme }\end{array}$ & \multicolumn{1}{c}{ Branş } & $\mathbf{n}$ & $\overline{\mathbf{X}}$ & SS & F & P & $\begin{array}{l}\text { Anlamlı } \\
\text { Fark }\end{array}$ \\
\hline Fikirlerde & (1) Sözel alan & 324 & 3,92 &, 64 & & & \\
ayrıntıya & (2) Sayısal alan & 183 & 3,83 &, 66 & & & \\
dikkat & (3) Uygulamalı alan & 46 & 3,62 &, 65 & 6,703 &, 00 & $1-3$ \\
& (4) Meslek Dersi & 153 & 3,67 &, 69 & & & \\
\hline Eleştirel & (1) Sözel alan & 330 & 3,88 &, 44 & & & \\
Düşünme & (2) Sayısal alan & 189 & 3,86 &, 46 & \multirow{2}{*}{, 466} & \multirow{2}{*}{, 22} & \\
Toplam & (3) Uygulamalı alan & 48 & 3,77 &, 54 & & & \\
& (4) Meslek Dersi & 157 & 3,80 &, 50 & & & \\
\hline
\end{tabular}

\section{3. Öğretmen Sayısı}

Ortaöğretim öğretmenlerinin eleştirel düşünme becerilerinin çalıştıkları okullardaki öğretmen sayısına göre anlamlı düzeyde farklılık gösterip göstermediğini tespit etmek için yapılan Kruskal-Wallis $\mathrm{H}$ testi sonucu elde edilen bulgular Tablo 5'te verilmiştir.

Tablo 5 incelendiğinde, ortaöğretim öğretmenlerinin eleştirel düşünme becerileri toplam puanının $\left(\mathrm{X}^{2}=12,019 ; \mathrm{p}<0.05\right)$ söz konusu öğretmenlerin çalıştıkları okullardaki öğretmen sayısına göre anlamlı düzeyde farklılık gösterdiği görülmektedir. Buna ek olarak ortaöğretim öğretmenlerinin eleştirel düşünme becerileri alt boyutları puanları incelendiğinde "Duygu, düşünce ve değerleri farkındalık" ( $\left.X^{2}=15,785 ; p<0.05\right)$, "Açık fikirlilik ve hoşgörü" ( $X^{2}=11,236$; $\left.p<0.05\right)$, ve "Eleştiriye açıklı" $\left(X^{2}=12,018\right.$; $\mathrm{p}<0.05)$ alt boyutlarındaki puanlarının öğretmenlerin çalıştıkları okullardaki öğretmen sayısına göre anlamlı düzeyde farklılık gösterdiği tespit edilmiştir. Farkın kaynağı için yapılan ikili karşılaştırmalarda Mann Whitney U testi yapılmıştır. İkili karşılaştırmaların sonucunda “Duygu, düşünce ve değerleri farkındalık" alt boyutu puanlarında 0-25 ile 101-125, 025 ile 126-150, 26-50 ile 101-125, 51-75 ile 101-125 sayıda öğretmeni olan okullar ; "Eleştiriye açıklık" alt boyutu puanlarında 26-50 ile 101-125, 5175 ile 101-125, 76-100 ile 101-125 sayıda öğretmeni olan okullar; "Eleştirel düşünme toplam" puanlarında ise 26-50 ile 101-125, 51-75 ile 101-125 sayıda öğretmeni olan okullar arasında anlamlı düzeyde farklılığın olduğu 
belirlenmiştir. "Açık fikirlilik ve hoşgörü" alt boyutu puanlarında ise $\mathrm{p}$ değeri 0,05’e çok yakın çıktığı için gruplar arasında farklılık çıkmamıştır.

Tablo 5. Ortaöğretim öğretmenlerinin çalıştıkları okullardaki öğretmen sayısına göre eleştirel düşünme becerilerine ilişkin yapılan Kruskal-Wallis H testi analizi (Sadece Mann Whitney $U$ testi sonucunda anlamlı farklılık gösterenler verilmiştir)

\begin{tabular}{|c|c|c|c|c|c|c|c|}
\hline Eleştirel Düşünme & $\begin{array}{l}\text { Öğretmen } \\
\text { Sayıs1 }\end{array}$ & $\mathbf{n}$ & Sira Ort. & $x^{2}$ & Sd & $\mathbf{P}$ & $\begin{array}{l}\text { Farkın } \\
\text { Kaynağı }\end{array}$ \\
\hline \multirow{7}{*}{$\begin{array}{l}\text { Duygu, düşünce, } \\
\text { değerleri farkındalık }\end{array}$} & (1) $0-25$ & 33 & 325,35 & \multirow{7}{*}{15,785} & \multirow{7}{*}{5} & \multirow{7}{*}{01} & \multirow{7}{*}{$\begin{array}{c}1-5 \\
1-6 \\
2-5 \\
3-5\end{array}$} \\
\hline & (2) $26-50$ & 162 & 350,20 & & & & \\
\hline & (3) $51-75$ & 249 & 334,39 & & & & \\
\hline & (4) $76-100$ & 139 & 339,28 & & & & \\
\hline & (5) $101-125$ & 50 & 231,26 & & & & \\
\hline & (6) $126-150$ & 28 & 333,39 & & & & \\
\hline & (6) $126-150$ & 29 & 362,28 & & & & \\
\hline \multirow[t]{6}{*}{ Eleştiriye açıklık } & (1) $0-25$ & 33 & 259,39 & \multirow{6}{*}{12,018} & \multirow{6}{*}{5} & \multirow{6}{*}{,04 } & \multirow{6}{*}{$\begin{array}{l}2-5 \\
3-5 \\
4-5\end{array}$} \\
\hline & (2) $26-50$ & 161 & 360,25 & & & & \\
\hline & (3) $51-75$ & 259 & 344,02 & & & & \\
\hline & (4) $76-100$ & 137 & 333,58 & & & & \\
\hline & (5) $101-125$ & 52 & 283,88 & & & & \\
\hline & (6) $126-150$ & 31 & 344,50 & & & & \\
\hline Eleştirel Düşünme & (1) $0-25$ & 36 & 306,88 & \multirow{6}{*}{12,019} & \multirow{6}{*}{5} & \multirow{6}{*}{, 04} & \multirow{6}{*}{$\begin{array}{l}1-5 \\
3-5\end{array}$} \\
\hline \multirow[t]{5}{*}{ Toplam } & (2) $26-50$ & 174 & 391,82 & & & & \\
\hline & (3) $51-75$ & 279 & 365,93 & & & & \\
\hline & (4) $76-100$ & 148 & 362,02 & & & & \\
\hline & (5) $101-125$ & 55 & 293,73 & & & & \\
\hline & (6) $126-150$ & 32 & 356,20 & & & & \\
\hline
\end{tabular}

Alanyazında öğretmen nüfusu değişkeninin incelendiği herhangi bir eleştirel düşünme çalışmasına rastlanmamıştır. Bu araştırmanın bulguları doğrultusunda ortaöğretim öğretmenlerinin eleştirel düşünme becerileri puanlarının 26-50 arası öğretmenin bulunduğu okullarda çalışan öğretmenlerde daha yüksek çıkmasının nedeni kalabalık olmayan okullarda çalışma standartlarının öğretmenlerin becerilerini geliştirmek için daha fazla fırsat bulma olasılığı yaratması olabilir. Küçük bir toplulukta bireylerin birbirini daha yakından tanıyarak ve kendi niteliklerini farkına vararak daha sağlıklı bir ortam oluşturduğu söylenebilir. Ayrıca gelişen samimi ilişkiler vasıtasıyla bireylerin eleştiriye açı olma özelliğini geliştirmelerini sağlayacak bir güven ortamı yaratması bu becerilerine katkı sağlayacak diğer bir sebep olabilir. 


\section{4. Öğrenci Sayısı}

Ortaöğretim öğretmenlerinin eleştirel düşünme becerilerinin çalıştıkları okullardaki öğrenci sayısına göre anlamlı düzeyde farklılık gösterip göstermediğini tespit etmek için yapılan Kruskal-Wallis $\mathrm{H}$ testi sonucu elde edilen bulgular Tablo 6'da verilmiştir.

Tablo 6 incelendiğinde, ortaöğretim öğretmenlerinin eleştirel düşünme becerileri toplam puanının $\left(X^{2}=9,622 ; p>0.05\right)$ söz konusu öğretmenlerin çalıştıkları okullardaki öğrenci sayısına göre anlamlı düzeyde farklılık göstermediği görülmektedir. Ancak ortaöğretim öğretmenlerinin eleştirel düşünme becerileri alt boyutlarının puanları incelendiğinde "Duygu, düşünce ve değerleri farkındalık" $\left(X^{2}=14,398 ; p<0.05\right)$ alt boyutu puanının öğretmenlerin çalıştıkları okullardaki öğrenci sayısına göre anlamlı düzeyde farklılık gösterdiği tespit edilmiştir. Farkın kaynağı için yapılan ikili karşılaştırmalarda Mann Whitney U testi yapılmıştır. İkili karşılaştırmaların sonucunda "Duygu, düşünce ve değerleri farkındalık" alt boyutu puanlarında 0-300 ile 1201-1500, 0-300 ile 1501-1800, 301-600 ile 1201-1500, 601-900 ile 1201-1500 sayıda öğrencisi bulunan okullar arasında anlamlı düzeyde farklılı̆̆ın olduğu belirlenmiştir.

Ortaöğretim öğretmenlerinin eleştirel düşünme becerileri toplam puanları çalıştıkları okullardaki öğrenci sayısı değişkenine göre anlamlı düzeyde farklılık göstermezken; alt boyutların puanları incelendiğinde "Duygu, düşünce ve değerleri farkındalık" alt boyutunda anlamlı düzeyde farklılığın çıtı̆̆g görülmektedir. Alanyazında öğrenci nüfusu değişkeninin incelendiği herhangi bir eleştirel düşünme çalışmasına rastlanmamıştır. Bu araştırma bulguları doğrultusunda ortaöğretim öğretmenlerinin eleştirel düşünme becerileri puanlarının 0-300 arası öğrencinin eğitim-öğretim gördüğü okullarda çalışan öğretmenlerde daha yüksek çımasının nedeni az sayıda öğrenciyle ilgilenen ve iş yükü azalan öğretmenlerin kendini geliştirmeye yönelik gücü kendisinde bulması olabilir. Ayrıca kendi duygu, düşünce ve değerlerine eğilebilme gücünü kendinde bulan öğretmenin becerilerine katkı sağlamak ve dolayısıyla öğrencilerine bunu yansıtabilmek için çaba gösterme fırsatını daha rahat bulduğu söylenebilir. 
Tablo 6. Ortaöğretim öğretmenlerinin çalıştıklarn okullardaki öğrenci sayısına göre eleştirel düşünme becerilerine ilişkin yapılan Kruskal-Wallis $\mathrm{H}$ testi analizi (Sadece Mann Whitney U testi sonucunda anlaml farklılık gösterenler verilmiştir)

\begin{tabular}{|c|c|c|c|c|c|c|c|}
\hline Eleştirel Düşünme & $\begin{array}{l}\text { Öğrenci } \\
\text { Sayısı }\end{array}$ & $\mathbf{n}$ & $\begin{array}{l}\text { Sira } \\
\text { Ort. }\end{array}$ & $\chi^{2}$ & Sd & $\mathbf{P}$ & $\begin{array}{l}\text { Farkın } \\
\text { Kaynağı }\end{array}$ \\
\hline \multirow{6}{*}{$\begin{array}{l}\text { Duygu, düşünce, } \\
\text { değerleri farkındalık }\end{array}$} & (1) $0-300$ & 20 & 412,50 & \multirow{6}{*}{14,398} & \multirow{6}{*}{5} & \multirow{6}{*}{,01 } & \\
\hline & (2)301-600 & 105 & 328,40 & & & & $1-5$ \\
\hline & (3)601-900 & 273 & 346,63 & & & & $1-6$ \\
\hline & (4)901-1200 & 118 & 324,08 & & & & $2-5$ \\
\hline & (5)1201-1500 & 101 & 276,31 & & & & $3-5$ \\
\hline & (6)1501-1800 & 40 & 316,00 & & & & \\
\hline Eleştirel Düşünme & (1) $0-300$ & 21 & 425,50 & \multirow{6}{*}{9,622} & \multirow{6}{*}{5} & \multirow{6}{*}{,09 } & \\
\hline \multirow[t]{5}{*}{ Toplam } & (2) $301-600$ & 112 & 356,44 & & & & \\
\hline & (3) $601-900$ & 296 & 378,69 & & & & \\
\hline & (4) 901-1200 & 138 & 354,28 & & & & \\
\hline & (5)1201-1500 & 110 & 321,32 & & & & \\
\hline & (6)1501-1800 & 42 & 325,14 & & & & \\
\hline
\end{tabular}

Öğretmenlerin okul sağlı̆̆ı algıları ile bu algıları bireysel özelliklere (cinsiyet, branş, okullarındaki öğretmen ve öğrenci sayısı) göre farklılı̆̆ı

Bu alt problem doğrultusunda ortaöğretim öğretmenlerinin okul sağlı̆̆1 algıları düzeyleri itibariyle Tablo 7'de verilmiştir:

Tablo 7. Ortaöğretimde çalışan öğretmenlerin okul să̆lı̆̆ı algıları

\begin{tabular}{llll}
\hline Örgüt Sağlığı & $\overline{\mathbf{X}}$ & SS & SKPA Anlami* \\
\hline Örgütsel Liderlik & 3,26 &, 67 & Her zaman \\
Çevresel Etkileşim & 3,00 &, 53 & Ara sira \\
Örgütsel Bütünlük & 2,90 &, 57 & Ara sıra \\
Örgütsel Kimlik & 3,11 &, 60 & Ara sira \\
Örgütsel Ürün & 3,13 &, 62 & Ara sıra \\
\hline
\end{tabular}

*Seçeneklere Göre Kodlanan Puan Aralı̆̆

Ortaöğretim öğretmenlerinin okul sağlığı algıları puan ortalamalarına göre söz konusu öğretmenlerin okullarının sağlığına ilişkin algılarının ortalamanın üzerinde olduğu görülmüştür. Alanyazındaki çalışmalar incelendiğinde benzer bulgulara rastlanmıştır. Kesik ve Balcı'ya (2015) göre AB Projelerine katılım gösteren okullarda görev yapan öğretmenlerin 
okul sağlığına ilişkin algılarının oldukça yüksek olduğu görülmüştür. Recepoğlu ve Özdemir (2014) ilköğretim okullarında çalışan öğretmenlerin örgüt sağlığına ilişkin algılarının genellikle olumlu olduğu sonucuna ulaşmıştır. Taneri (2011) ilköğretim okullarında görev yapan öğretmenlerin okullarının örgüt sağlığına dair algılarının yüksek düzeyde olduğunu tespit etmiştir. Buna ek olarak Ordu'ya (2011) göre ise ilköğretim okullarında çalışan öğretmenlerin örgüt sağlığına ilişkin verdikleri cevaplar "ara sıra" düzeyindedir. Ayrıca öğretmenler "örgütsel liderlik" ve "örgütsel kimlik" alt boyutundaki maddelerin okullarında "her zaman" gösterildiğini; “örgütsel ürün", "çevresel etkileşim" ve "örgütsel bütünlük" alt boyutlarındaki maddelerin ise "ara sıra" gösterildiğini belirtmişlerdir. Diğer taraftan Yıldı'a (2014) göre meslek lisesi yöneticilerinin diğer okul türü yöneticilerine göre örgüt sağllğı alt boyut puanlarının daha düşük olduğu görülmüştür.

Alanyazın ve bu araştırmanın bulguları doğrultusunda ortaöğretim öğretmenlerin okul sağlığına ilişkin algılarının yüksek düzeyde olmasının nedeni okula aidiyet duygusunu kazanmalarından kaynaklanmış olabilir. Buna ek olarak söz konusu öğretmenlerin okullarındaki okul yöneticilerinin etkili bir liderlik sergilediği, performans ve çıktı odaklı bir eğitim öğretim sürecinin var olduğu, çalışanlar arasında birlik ve beraberlik duygusunun geliştiği, çevreyle ilişkilerin pozitif yönde olduğu bir örgüt kültürünün hakim olduğu söylenebilir.

\section{Cinsiyet}

Ortaöğretim öğretmenlerinin okul sağlı̆̆ına ilişkin algılarının cinsiyete göre anlamlı düzeyde farklılık gösterip göstermediğini tespit etmek için yapılan t testi sonucu elde edilen bulgular Tablo 8' de verilmiştir.

Tablo 8 incelendiğinde, ortaöğretim öğretmenlerinin okul sağlığı alg1larının örgütsel kimlik puanları $(t=1,976 ; \mathrm{p}<0.05)$ cinsiyete göre anlamlı düzeyde farklılık göstermektedir. Ancak ortaöğretim öğretmenlerinin okul sağlığı algılarının örgütsel liderlik ( $t=1,338$; $p>0.05)$, çevresel etkileşim ( $t=, 675 ; p>0.05)$, örgütsel bütünlük ( $t=, 498: p>0.05)$ ve örgütsel ürün $(t=1,252 ; p>0.05)$ boyutları cinsiyete göre anlamlı düzeyde farklılık göstermemektedir. Ortaöğretim öğretmenlerinin okul sağlığına ilişkin algıları- 
nın örgütsel kimlik boyutunda kadınların puan ortalamaları $(\overline{\mathbf{X}}=3,15)$ erkeklerin puan ortalamalarından $(\overline{\mathbf{X}}=3,05)$ daha yüksektir. Ortaöğretim öğretmenlerinin okul sağlığı algıları örgüt sağlığ1 alt boyutlarından "örgütsel kimlik" boyutunda cinsiyete göre anlamlı düzeyde farklılık göstermektedir ve kadın öğretmenlerin puan ortalamaları söz konusu boyutta erkek öğretmenlerin puan ortalamalarından daha yüksek çıkmıştır.

Tablo 8. Ortaöğretim öğretmenlerinin cinsiyete göre okul sağliğı algılarına ilişkin yapılan t testi analizi sonuçları (Sadece Sidak testi sonucunda anlamlı farklılık gösterenler verilmiştir)

\begin{tabular}{llllllll}
\hline Örgüt Sağlığı & Cinsiyet & $\mathbf{n}$ & $\overline{\mathbf{X}}$ & SS & Sd & $\mathbf{t}$ & $\mathbf{P}$ \\
\hline \multirow{2}{*}{ Örgütsel kimlik } & Kadın & 416 & 3,15 &, 60 & \multirow{2}{*}{665} & \multirow{2}{*}{1,976} & \multirow{2}{*}{, 049} \\
& Erkek & 251 & 3,05 &, 58 & & & \\
\hline
\end{tabular}

Alanyazındaki araştırmaların bulguları incelendiğinde Olgun'a (2012) göre ilköğretim okul yöneticilerinin okul sağlı̆̆ı puanları cinsiyete göre anlamlı düzeyde farklılık göstermektedir. Benzer şekilde Recepoğlu ve Özdemir'e (2014) göre de ilköğretim okullarının örgüt sağlığının öğretmenlerin cinsiyetine göre anlamlı düzeyde farklılık gösterdiği tespit edilmiştir. Öte yandan Kesik ve Balc (2015) ile Ebcim'e (2012) göre öğretmenlerin örgüt sağlığı algıları cinsiyet değişkenine göre anlamlı düzeyde farklılık göstermemektedir. Gürkan'a (2006) göre ise ilköğretim okullarında görev yapan öğretmenlerin örgüt sağllğı düzeyi alt boyutlarından "akademik öneme", "kurumsal bütünlüğe", "kaynak desteğine" ve "öğretmen bağlılığına" ilişkin algıları cinsiyete göre anlamlı düzeyde farklılık göstermemektedir. Alanyazın ve bu araştırmanın bulguları doğrultusunda kadınların puan ortalamalarının yüksek çıkmasının nedeni öğretmenlik mesleğinin bir kadın mesleği olarak görülmesi ve toplumun yarattığ etkiyle birlikte onların okullarını daha benimsemelerine yol açmış olabilir. Eskicumalı, Yaman ve Yaman'ın (2014) araştırmasındaki kız öğrencilerin daha çok eğitim fakültelerini tercih ettiğine ve bu eğitim fakültelerindeki öğretmen adaylarının çoğunluğunun öğretmenliği bir kadın mesleği olarak gördügüne ilişkin ifadeler de bu araştırmanın bulgularını desteklemektedir. 


\section{Branş}

Ortaöğretim öğretmenlerinin branşa göre okul sağlığı algılarına ilişkin yapılan tek yönlü varyans testi sonucu elde edilen bulgular Tablo 9'da verilmiştir.

Tablo 9 incelendiğinde, ortaöğretim öğretmenlerinin okul sağlığı alg1ları "çevresel etkileşim" ( $F=3,532 ; p<0.05)$, "örgütsel kimlik" ( $F=3,560$; $\mathrm{p}<0.05)$, “örgütsel bütünlük" $(\mathrm{F}=4,243 ; \mathrm{p}<0.05)$ ve “örgütsel ürün” $(\mathrm{F}=3,459 ; \mathrm{p}<0.05)$ puanları branşa göre anlamlı düzeyde farklılık göstermektedir. "Örgütsel liderlik" boyutunda anlamlı düzeyde farklılık elde edilmemiştir. Ortaöğretim öğretmenlerinin okul sağlığı algılarının branşa göre farkının kaynağını bulmak için yapılan Sidak analizinde; "çevresel etkileşim", "örgütsel kimlik" ve "örgütsel ürün" puanlarında sözel alan ile meslek derslerini veren öğretmenler; "örgütsel bütünlük" puanlarında ise sayısal alan ile meslek dersilerini veren öğretmenler arasında anlamlı düzeyde farklılığın olduğu tespit edilmiştir. "Çevresel etkileşim”, "örgütsel kimlik" ve "örgütsel ürün" alt boyutlarında sözel dersleri veren öğretmenlerin puanlarl; "örgütsel bütünlük" alt boyutunda ise sayısal dersleri veren öğretmenlerin puanları diğer alanların derslerine giren öğretmenlerin puanlarından daha yüksek bulunmuştur.

Alanyazındaki araştırmaların bulguları incelendiğinde bazı araştırmalarda (Kesik ve Balc1, 2015; Recepoğlu ve Özdemir, 2014; Olgun, 2012) öğretmenlerin okullarının sağlığına ilişkin algılarının branşlarına göre anlamlı düzeyde farklılık gösterdiği görülmüştür. Diğer taraftan Ebcim'e (2012) göre öğretmenlerin örgüt sağllğı algıları branş değişkenine göre anlamlı düzeyde farklılık göstermemektedir. Alanyazın ve bu araştırmanın bulguları doğrultusunda sözel ve sayısal dersleri veren öğretmenlerin örgüt sağlığı puanlarının yüksek çımasının nedeni söz konusu derslerin yerleştirme sınavlarına daha fazla yönelik olması olabilir. Öğrencilerin derse karşı pozitif tutumunun, okul yöneticilerinin ve çalışanlarının akademik başarıyı arttırma çabalarının ve toplumda bu derslere verilen önemin öğretmenleri de güdülediği ve mesleki anlamda tatmin ettiği söylenebilir. 
Tablo 9. Ortaöğretim öğretmenlerinin branşa göre okul să̆lı̆̆ı algılarına ilişkin yapılan tek yönlï varyans testi analizi (Sadece Sidak testi sonucunda anlamlı farklılık gösterenler verilmiştir)

\begin{tabular}{|c|c|c|c|c|c|c|c|}
\hline $\begin{array}{l}\text { Örgüt } \\
\text { Sağlığ1 }\end{array}$ & Branş & $\mathbf{N}$ & $\overline{\mathbf{X}}$ & SS & $\mathbf{F}$ & $\mathbf{P}$ & $\begin{array}{l}\text { Anlaml } \\
\text { fark }\end{array}$ \\
\hline Çevresel & (1) Sözel alan & 279 & 3,05 & ,51 & \multirow{4}{*}{3,532} & \multirow{4}{*}{,02 } & \multirow{4}{*}{$1-4$} \\
\hline \multirow[t]{3}{*}{ etkileşim } & (2) Sayısal alan & 171 & 3,02 &, 52 & & & \\
\hline & (3) Uygulamalı alan & 39 & 2,95 &, 55 & & & \\
\hline & (4) Meslek Dersi & 139 & 2,88 &, 58 & & & \\
\hline Örgütsel & (1) Sözel alan & 307 & 3,17 & ,54 & \multirow{4}{*}{3,560} & & \multirow{4}{*}{$1-4$} \\
\hline \multirow[t]{3}{*}{ Kimlik } & (2) Sayısal alan & 174 & 3,12 &, 57 & & \multirow{3}{*}{, 01} & \\
\hline & (3) Uygulamalı alan & 41 & 3,09 & 67 & & & \\
\hline & (4) Meslek Dersi & 145 & 2,98 & 69 & & & \\
\hline \multirow{4}{*}{$\begin{array}{l}\text { Örgütsel } \\
\text { bütünlük }\end{array}$} & (1) Sözel alan & 296 & 2,92 & 59 & \multirow{4}{*}{4,243} & \multirow{4}{*}{01} & \multirow{4}{*}{$2-4$} \\
\hline & (2) Sayısal alan & 173 & 2,99 & ,53 & & & \\
\hline & (3) Uygulamalı alan & 42 & 2,83 & 48 & & & \\
\hline & (4) Meslek Dersi & 134 & 2,77 &, 60 & & & \\
\hline \multirow{4}{*}{$\begin{array}{l}\text { Örgütsel } \\
\text { ürün }\end{array}$} & (1) Sözel alan & 292 & 3,19 & ,59 & \multirow{4}{*}{3,459} & \multirow{4}{*}{,02 } & \multirow{4}{*}{$1-4$} \\
\hline & (2) Sayısal alan & 178 & 3,15 &, 57 & & & \\
\hline & (3) Uygulamalı alan & 41 & 3,17 & 61 & & & \\
\hline & (4) Meslek Dersi & 145 & 2,99 & ,73 & & & \\
\hline
\end{tabular}

\section{3. Öğretmen Sayısı}

Ortaöğretim öğretmenlerinin çalıştıkları okullardaki öğretmen sayısına göre okul sağlığı algılarına ilişkin yapılan Kruskal-Wallis $\mathrm{H}$ testi sonucu elde edilen bulgular Tablo 10'da verilmiştir.

Tablo 10 incelendiğinde, ortaöğretim öğretmenlerinin okul sağlı̆̆ 1 algıları "örgütsel liderlik" ( $X^{2}=33,093$; $\left.p<0.05\right)$, “çevresel etkileşim" $\left(X^{2}=29,194 ; p<0.05\right)$, "örgütsel kimlik" $\left(X^{2}=15,301 ; p<0.05\right)$, "örgütsel bütünlük" $\left(X^{2}=46,748 ; p<0.05\right)$ ve "örgütsel ürün" $\left(X^{2}=44,007 ; p<0.05\right)$ puanlarının tamamı öğretmen sayısına göre anlamlı düzeyde farklılık göstermektedir. Farkın kaynağı için yapılan ikili karşılaştırmalarda Mann Whitney U testi kullanılmıştır. İkili karşılaştırmaların sonucunda “örgütsel liderlik" alt boyutu puanlarında 0-25 ile 101-125, 26-50 ile 51-75, 26-50 ile 101-125, 26-50 ile 126-150, 51-75 ile 76-100, 51-75 ile 101-125, 76-100 ile 101125, 76-100 ile 126-150 sayıda öğretmeni olan okullar; "çevresel etkileşim" alt boyutu puanlarında 0-25 ile 51-75, 0-25 ile 101-125, 26-50 ile 51-75, 26- 
50 ile 76-100, 26-50 ile 101-125, 76-100 ile 101-125, 101-125 ile 126-150 sayıda öğretmeni olan okullar arasında anlamlı düzeyde farklılığın olduğu görülmüştür.

Tablo 10. Ortä̈ğretim öğretmenlerinin çalıştıklar okullardaki öğretmen sayısına göre okul sağlı̆̆ı algılarına ilişkin yapılan Kruskal-Wallis $\mathrm{H}$ testi analizi (Sadece Mann Whitney $U$ testi sonucunda anlamlı farklılık gösterenler verilmiştir)

\begin{tabular}{|c|c|c|c|c|c|c|c|}
\hline $\begin{array}{l}\text { Örgüt } \\
\text { Sağllğı }\end{array}$ & $\begin{array}{l}\text { Öğretmen } \\
\text { Sayısı }\end{array}$ & $\mathbf{n}$ & Sira Ort. & $x^{2}$ & $S d$ & $\mathbf{P}$ & $\begin{array}{l}\text { Farkın } \\
\text { Kaynağı }\end{array}$ \\
\hline Örgütsel & (1) $0-25$ & 32 & 333,80 & \multirow{6}{*}{33,093} & \multirow{6}{*}{5} & \multirow{6}{*}{,00 } & $1-5$ \\
\hline \multirow[t]{5}{*}{ liderlik } & (2) $26-50$ & 161 & 375,83 & & & & $2-3$ \\
\hline & (3) $51-75$ & 245 & 297,74 & & & & $2-5$ \\
\hline & (4) $76-100$ & 133 & 346,44 & & & & $2-6$ \\
\hline & (5) $101-125$ & 46 & 236,15 & & & & $3-4,3-5$ \\
\hline & (6) $126-150$ & 28 & 259,29 & & & & $4-5,4-6$ \\
\hline \multirow{6}{*}{$\begin{array}{l}\text { Çevresel } \\
\text { etkileşim }\end{array}$} & (1) $0-25$ & 33 & 338,47 & \multirow{6}{*}{29,194} & \multirow{6}{*}{5} & \multirow{6}{*}{,00 } & $1-3$ \\
\hline & (2) $26-50$ & 149 & 359,50 & & & & $1-5$ \\
\hline & (3) $51-75$ & 243 & 292,41 & & & & $2-3$ \\
\hline & (4) $76-100$ & 128 & 338,45 & & & & $2-4$ \\
\hline & (5) $101-125$ & 46 & 218,22 & & & & $2-5$ \\
\hline & (6) $126-150$ & 29 & 288,14 & & & & $4-5,5-6$ \\
\hline \multirow{6}{*}{$\begin{array}{l}\text { Örgütsel } \\
\text { Kimlik }\end{array}$} & (1) $0-25$ & 33 & 317,52 & \multirow{6}{*}{15,301} & \multirow{6}{*}{5} & \multirow{6}{*}{,01 } & $1-5$ \\
\hline & (2) $26-50$ & 168 & 361,59 & & & & $2-3$ \\
\hline & (3) $51-75$ & 258 & 330,12 & & & & $2-5$ \\
\hline & (4) $76-100$ & 134 & 350,35 & & & & $2-6$ \\
\hline & (5) $101-125$ & 48 & 253,36 & & & & $3-4$ \\
\hline & (6) $126-150$ & 26 & 279,69 & & & & $4-5$ \\
\hline \multirow{6}{*}{$\begin{array}{l}\text { Örgütsel } \\
\text { bütünlük }\end{array}$} & (1) $0-25$ & 33 & 369,44 & \multirow{6}{*}{46,748} & \multirow{6}{*}{5} & \multirow{6}{*}{,00 } & \\
\hline & (2) $26-50$ & 158 & 397,97 & & & & $2-5$ \\
\hline & (3) $51-75$ & 249 & 290,82 & & & & $2-6$ \\
\hline & (4) $76-100$ & 130 & 310,22 & & & & $3-5$ \\
\hline & (5) $101-125$ & 46 & 232,92 & & & & $4-5$ \\
\hline & (6) $126-150$ & 29 & 338,17 & & & & \\
\hline \multirow{6}{*}{$\begin{array}{l}\text { Örgütsel } \\
\text { ürün }\end{array}$} & (1) $0-25$ & 33 & 346,92 & \multirow{6}{*}{44,007} & \multirow{6}{*}{5} & \multirow{6}{*}{,00 } & $1-5$ \\
\hline & (2) $26-50$ & 162 & 395,20 & & & & $2-3$ \\
\hline & (3) $51-75$ & 253 & 296,92 & & & & $2-4$ \\
\hline & (4) $76-100$ & 131 & 350,85 & & & & $2-5$ \\
\hline & (5) $101-125$ & 50 & 245,61 & & & & $2-6,3-4$ \\
\hline & (6) $126-150$ & 27 & 246,74 & & & & $4-5,4-6$ \\
\hline
\end{tabular}

Buna ek olarak "örgütsel kimlik" alt boyutu puanlarında 0-25 ile 101125, 26-50 ile 51-75, 26-50 ile 101-125, 26-50 ile 126-150, 51-75 ile 76-100, 76- 
100 ile 101-125 sayıda öğretmeni olan okullar, "örgütsel bütünlük" alt boyutu puanları 26-50 ile 101-125, 26-50 ile 126-150, 51-75 ile 101-125, 76-100 ile 101-125 sayıda öğretmeni olan okullar ve "örgütsel ürün" alt boyutu puanlarında 0-25 ile 101-125, 26-50 ile 51-75, 26-50 ile 76-100, 26-50 ile 101125, 26-50 ile 126-150, 51-75 ile 76-100, 76-100 ile 101-125, 76-100 ile 126150 sayıda öğretmeni olan okullar arasında anlamlı düzeyde farklılığın olduğu da tespit edilmiştir. Ortaöğretim öğretmenlerinin okul sağliğı alg1ları örgüt sağlığının tüm boyutlarında 26-50 arasında öğretmenin bulunduğu okullarda daha yüksek çıkmıştır.

Alanyazındaki çalışmalar incelendiğinde öğretmenlerin çalıştıkları okullardaki öğretmen sayısı değişkenine göre okul sağlığı algılarına ilişkin bir çalışmaya rastlanmamıştır. Bu araştırmanın bulguları doğrultusunda ortaöğretim öğretmenlerinin okul sağlığı algılarının 26-50 arasında öğretmenin çalıştığı okullarda yüksek çıkmasının nedeni okulda çalışan personelin az olmasının örgüt iklimini ve kültürünü pozitif yönde etkilemesinden kaynaklanmış olabilir. Az sayıda çalışanın olduğu okullarda öğretmenlerin daha samimi ilişkiler geliştirmesi ve nicelikten ziyade niteliğe odaklanması da diğer bir sebep olarak gösterilebilir. Diğer taraftan 025 öğretmenin çalıştığı okullarda örgüt sağlı̆̆ı alt boyutları ortalama puanları 26-50 öğretmenin çalıştığı okullardaki puanlardan daha düşük çımıştır. Bu bulgunun elde edilmesi öğretmen sayısı açısından küçük ölçekli olan okullarda üst-ast ilişkilerinin en alt seviyeye inmesinden ve yatay iletişimin öne çıkmasından kaynaklanmış olabilir. Ayrıca az çalışanın olması bireysel farklılıkları ve çok yönlü iletişimi azaltacağından dolayı tekdüzeliğe sebep olmuş olabilir

\section{4. Öğrenci Sayısı}

Ortaöğretim öğretmenlerinin çalıştıkları okullardaki öğrenci sayısına göre okul sağlı̆̆ 1 algılarına ilişkin yapılan Kruskal-Wallis H testi sonucu elde edilen bulgular Tablo 11'de verilmiştir.

Tablo 11 incelendiğinde, ortaöğretim öğretmenlerinin okul sağlığı algıları "örgütsel liderlik" $\left(X^{2}=12,273 ; p<0.05\right)$, "çevresel etkileşim" $\left(X^{2}=26,638 ; p<0.05\right)$, “örgütsel kimlik" $\left(X^{2}=11,798 ; p<0.05\right)$, “örgütsel bü- 
tünlük" $\left(X^{2}=26,163 ; p<0.05\right)$ ve "örgütsel ürün" $\left(X^{2}=24,727 ; p<0.05\right)$ puanlarının tamamı öğrenci sayısına göre anlamlı düzeyde farklılık göstermektedir.

Tablo 11. Ortaöğretim öğretmenlerinin çalıştıklarn okullardaki öğrenci sayısına göre okul sağlığı algılarına ilişkin yapılan Kruskal-Wallis $\mathrm{H}$ testi analizi

\begin{tabular}{|c|c|c|c|c|c|c|c|}
\hline Örgüt Sağlığ1 & $\begin{array}{l}\text { Öğrenci } \\
\text { Sayısı }\end{array}$ & $\mathbf{N}$ & Sira Ort. & $\chi^{2}$ & Sd & $\mathbf{P}$ & $\begin{array}{l}\text { Farkın } \\
\text { Kaynağı }\end{array}$ \\
\hline \multirow[t]{6}{*}{ Örgütsel liderlik } & (1) $0-300$ & 20 & 374,88 & \multirow{6}{*}{12,273} & \multirow{6}{*}{5} & \multirow{6}{*}{,03 } & \\
\hline & (2) $301-600$ & 104 & 347,70 & & & & $1-5$ \\
\hline & (3) $601-900$ & 269 & 332,17 & & & & $2-4$ \\
\hline & (4) $901-1200$ & 117 & 295,33 & & & & $2-5$ \\
\hline & (5) $1201-1500$ & 92 & 277,36 & & & & $3-5$ \\
\hline & (6) 1501-1800 & 39 & 325,10 & & & & \\
\hline \multirow[t]{6}{*}{ Çevresel etkileşim } & (1) $0-300$ & 20 & 411,78 & \multirow{6}{*}{26,638} & \multirow{6}{*}{5} & \multirow{6}{*}{,00 } & $1-3$ \\
\hline & (2) $301-600$ & 99 & 335,12 & & & & $1-4$ \\
\hline & (3) $601-900$ & 256 & 331,32 & & & & $1-5$ \\
\hline & (4) $901-1200$ & 119 & 264,88 & & & & $2-3$ \\
\hline & (5) 1201-1500 & 95 & 265,84 & & & & $2-4$ \\
\hline & (6) $1501-1800$ & 36 & 350,53 & & & & $2-5,5-6$ \\
\hline \multirow[t]{6}{*}{ Örgütsel Kimlik } & (1) $0-300$ & 20 & 380,18 & \multirow{6}{*}{11,798} & \multirow{6}{*}{5} & \multirow{6}{*}{,04 } & \\
\hline & (2) $301-600$ & 108 & 327,81 & & & & $1-4$ \\
\hline & (3) $601-900$ & 279 & 352,86 & & & & 125 \\
\hline & (4) $901-1200$ & 123 & 315,01 & & & & $-4,2-5$ \\
\hline & (5) $1201-1500$ & 97 & 283,93 & & & & $3-4,3-5$ \\
\hline & (6) $1501-1800$ & 35 & 334,59 & & & & \\
\hline \multirow[t]{6}{*}{ Örgütsel bütünlük } & (1) $0-300$ & 21 & 441,40 & \multirow{6}{*}{26,163} & \multirow{6}{*}{5} & \multirow{6}{*}{, 00} & \multirow{6}{*}{$3-5$} \\
\hline & (2) $301-600$ & 102 & 367,38 & & & & \\
\hline & (3) $601-900$ & 265 & 320,38 & & & & \\
\hline & (4) $901-1200$ & 120 & 284,24 & & & & \\
\hline & (5) $1201-1500$ & 92 & 276,97 & & & & \\
\hline & (6) 1501-1800 & 40 & 347,16 & & & & \\
\hline \multirow[t]{6}{*}{ Örgütsel ürün } & (1) $0-300$ & 20 & 414,15 & \multirow{6}{*}{24,727} & \multirow{6}{*}{5} & \multirow{6}{*}{,00 } & \multirow{6}{*}{$\begin{array}{l}1-4 \\
1-5 \\
2-4 \\
2-5 \\
3-4,3-5\end{array}$} \\
\hline & (2) $301-600$ & 103 & 369,92 & & & & \\
\hline & (3) $601-900$ & 274 & 340,07 & & & & \\
\hline & (4) 901-1200 & 124 & 281,81 & & & & \\
\hline & (5) $1201-1500$ & 96 & 278,01 & & & & \\
\hline & (6) $1501-1800$ & 35 & 333,70 & & & & \\
\hline
\end{tabular}

Farkın kaynağı için yapılan ikili karşılaştırmalarda Mann Whitney U testi kullanılmıştır. İkili karşılaştırmaların sonucunda "örgütsel liderlik" alt boyutu puanlarında 0-300 ile 1201-1500, 301-600 ile 901-1200, 301-600 
ile 1201-1500, 601-900 ile 1201-1500 sayıda öğrencisi olan okullar; "çevresel etkileşim" alt boyutu puanlarında 0-300 ile 601-900, 0-300 ile 901-1200, 0300 ile 1201-1500, 301-600 ile 601-900, 301-600 ile 901-1200, 301-600 ile 12011500, 1201-1500 ile 1501-1800 sayıda öğrencisi olan okullar arasında anlamlı düzeyde farklılığın olduğu görülmüştür. "Örgütsel kimlik" alt boyutu puanlarında 0-300 ile 901-1200, 0-300 ile 1201-1500, 301-600 ile 9011200, 301-600 ile 1201-1500, 601-900 ile 901-1200, 601-900 ile 1201-1500, 9011200 ile 1501-1800, 1201-1500 ile 1501-1800 sayıda öğrencisi bulunan okullar, "örgütsel bütünlük" alt boyutu puanları 601-900 ile 1201-1500 sayıda ve "örgütsel ürün" alt boyutu puanlarında 0-300 ile 901-1200, 0-300 ile 1201-1500, 301-600 ile 901-1200, 301-600 ile 1201-1500, 601-900 ile 901-1200, 601-900 ile 1201-1500 sayıda öğrencisi olan okullar arasında anlamlı düzeyde farklılığın olduğu tespit edilmiştir. Ortaöğretim öğretmenlerinin okul sağlığı algıları örgüt sağlığının alt boyutlarında 0-300 arasında öğrencinin bulunduğu okullarda daha yüksek çıkmıştır.

Ortaöğretim öğretmenlerinin okul sağlığı algıları örgüt sağlı̆̆ının alt boyutlarında çalıştıkları okullardaki öğrenci sayısına anlamlı düzeyde farklılık göstermektedir. Alanyazındaki araştırmalar incelendiğinde Olgun’a (2012) göre öğrenci nüfusu değişkenine göre öğretmenlerin örgüt sağlığı ölçeğine verdikleri cevaplarda anlamlı düzeyde farklılık çıkmıştır. Bunun dışında alanyazında öğretmenlerin çalıştıkları okullardaki öğrenci sayısı değişkenine göre okul sağlığı algılarına ilişkin bir çalışmaya rastlanmamıştır. Toprakçı'ya (2013) göre öğrenci sayısındaki artış; kaynak ve olanakların paylaşılmasına, etkileşime, öğretmeye, öğrenmeye, öğrenci-öğrenci ve öğrenci-öğretmen etkileşimine zarar vermekte ya da izin vermemektedir. Ayrıca öğrenci sayısının fazlalığı yerleşim düzeninin bozulmasına, estetiğin kaybolmasına, aydınlatmanın yetersizleşmesine, dersliğin daha çok ve çabuk kirlenmesine, isı ve hava koşullarının kötüleşmesine yol açabilmektedir.

Alanyazın ve bu araştırmanın bulguları doğrultusunda, 0-300 arasında öğrencinin eğitim-öğretim gördüğü okullarda çalışan öğretmenlerin okul sağlığı algılarının yüksek çıkmasının nedeni az sayıda öğrencinin öğrenim gördüğü okullarda iş yükünün az olması, akademik başarıyı arttırmak için nicelikten çok niteliğe odaklanma ihtimalinin olması söylenebilir. Daha az sayıda öğrenciyle ilgilenen öğretmenler öğrenciyi daha yakından tanıyabilmekte ve öğretim yöntem-tekniklerini daha az sayıda öğrenciye 
uygulayabilme fırsatını yakalayabilmektedir. Dolayısıyla akademik başarıyı ve motivasyonu sağlamakla görevli olan öğretmen ve okul yöneticilerinin performansının da bundan pozitif yönde etkilendiği söylenebilir.

\section{Öğretmenlerin okul sağhlı̆ı algıları ile eleştirel düşünme becerileri arasındaki ilişki}

Ortaöğretim öğretmenlerinin okul sağllğ ${ }_{1}$ algıları ile eleştirel düşünme becerileri arasındaki ilişkiyi belirlemek için korelasyon analizi yapılmıştır. $\mathrm{Bu}$ alt problem doğrultusunda yapılan analiz sonucunda elde edilen bulgular Tablo 12' de verilmektedir.

Tablo 12'deki bulgular incelendiğinde; ortaöğretim öğretmenlerinin eleştirel düşünme becerileri toplam puanları ile örgüt sağlığı alt boyutlarindan "Örgütsel liderlik" ( $\left.\mathrm{r}=, 195^{* *}\right)$, “Çevresel etkileşim” ( $\left.\mathrm{r}=, 182^{* *}\right)$, “Örgütsel kimlik" ( $\left.\mathrm{r}=, 198^{* *}\right)$, "Örgütsel bütünlük" $\left(\mathrm{r}=, 195^{* *}\right)$ ve “Örgütsel ürün" ( $\left.\mathrm{r}=, 171^{* *}\right)$ arasındaki ilişkinin olumlu yönde düşük düzeyde bir ilişki olduğu tespit edilmiştir. Buna ek olarak örgüt sağlı̆̆ ve eleştirel düşünmenin alt boyutları arasındaki ilişki de incelenmiştir. Buna göre eleştirel düşünme becerileri alt boyutları ile örgüt sağlığı alt boyutları arasinda olumlu yönde düşük düzeyde bir ilişki bulunmuştur.

Alanyazın incelendiğinde söz konusu iki değişkenin ilişkisini inceleyen herhangi bir çalışmaya rastlanmamıştır. Değişkenler ayrı ayrı ele alındığında; Güçlü, Recepoğlu ve Kılınç'a (2014) göre örgüt sağlığının iş motivasyonu ile pozitif yönde anlamlı ilişkisinin olduğu görülmektedir. Benzer şekilde Ebcim'e (2012) göre öğretmenlerin motivasyon düzeyleri ile örgüt sağlığı algıları arasında pozitif yönlü manidar bir ilişki bulunmaktadır. Özdemir'e (2012) göre ise okul kültürünün "destek" ve "başarı" boyutları ile okul sağlığının "mesleki liderlik" ve "kaynak desteği" boyutları arasında pozitif yönde bir ilişki vardır. Ordu'ya (2011) göre örgütsel yap1nın "karmaşıklık" ve "formalleşme" özellikleri örgüt sağlı̆̆ 1 ile pozitif yönde, "merkezileşme" boyutu ile negatif yönde ilişkilidir. 
Tablo 12. Ortä̈̆gretim öğretmenlerinin okul sağhı̆̆ algıları ile eleştirel düşünme becerileri arasındaki ilişki

\begin{tabular}{|c|c|c|c|c|c|c|c|c|c|c|c|c|c|c|c|c|}
\hline & 1 & 2 & 3 & 4 & 5 & 6 & 7 & 8 & 9 & 10 & 11 & 12 & 13 & 14 & 15 & 16 \\
\hline Liderlik & 1 & & & & & & & & & & & & & & & \\
\hline Etkileşim &, $812^{* *}$ & 1 & & & & & & & & & & & & & & \\
\hline Kimlik &, $780^{* *}$ &, $795^{* *}$ & 1 & & & & & & & & & & & & & \\
\hline Bütünlük &, $756^{* *}$ &, $743^{* *}$ &, $612^{* *}$ & 1 & & & & & & & & & & & & \\
\hline Ürün &, $855^{* *}$ &, $849^{* *}$ &, $841^{* *}$ &, $713^{* *}$ & 1 & & & & & & & & & & & \\
\hline Düzene koyma &, $118^{*}$ &, $110^{* *}$ &, $138^{* *}$ &, $165^{* *}$ &, $087^{*}$ & 1 & & & & & & & & & & \\
\hline Sorgulama &, 063 & 071 & 079 &, 029 &, 063 &, $388^{* *}$ & 1 & & & & & & & & & \\
\hline Farkındalık &, $196^{* *}$ &, $183^{* *}$ &, $171^{* *}$ &, $181^{* *}$ &, $173^{* *}$ &, $572^{* *}$ &, $642^{* *}$ & 1 & & & & & & & & \\
\hline Problem çözme &, $101^{* *}$ &, $101^{* *}$ & 073 &, $166^{* *}$ &, $080^{*}$ &, $505^{* *}$ &, $547^{* *}$ &, $544^{* *}$ & 1 & & & & & & & \\
\hline Açık fikirlilik &, $141^{* *}$ &, $116^{* *}$ & $158^{* *}$ &, $110^{* *}$ &, $151^{* *}$ &, $416^{* *}$ &, $557^{* *}$ &, $616^{* *}$ &, $509^{* *}$ & 1 & & & & & & \\
\hline Eşduyum &, $175^{* *}$ &, $141^{* *}$ &, $182^{* *}$ &, $182^{* *}$ &, $157^{* *}$ &, $598^{* *}$ &, $333^{* *}$ & $436^{* *}$ &, $386^{* *}$ &, $391^{* *}$ & 1 & & & & & \\
\hline $\begin{array}{l}\text { Kendini } \\
\text { geliştirme }\end{array}$ & $103^{* *}$ &, $106^{* *}$ &, $125^{* *}$ &, $102^{*}$ &, $119 * *$ &, $472^{* *}$ & $658^{* *}$ &, $685^{* *}$ &, $584^{* *}$ &, $593^{* *}$ &, $328^{* *}$ & 1 & & & & \\
\hline Eleştiriye açıklık &, $165^{* *}$ &, $175^{* *}$ &, $208^{* *}$ &, $200^{* *}$ &, $121^{* *}$ &, $503^{* *}$ &, $171^{* *}$ &, $325^{* *}$ &, $204^{* *}$ &, $332^{* *}$ &, $470^{* *}$ &, $267^{* *}$ & 1 & & & \\
\hline Ayrıntıya dikkat &, $110^{* *}$ &, $128^{* *}$ &, $103^{* *}$ &, $142^{* *}$ & 064 &, $526^{* *}$ &, $391^{* *}$ &, $422^{* *}$ &, $439^{* *}$ &, $376^{* *}$ &, $366^{* *}$ &, $429^{* *}$ &, $339 * *$ & 1 & & \\
\hline Akılcı düşünme &, $127^{* *}$ &, $126^{* *}$ &, $090^{* *}$ &, $140^{* *}$ &, $122^{* *}$ &, $448^{* *}$ &, $486^{* *}$ &, $535^{* *}$ &, $461^{* *}$ &, $401^{* *}$ &, $306^{* *}$ & ,491 &, $269^{* *}$ &, $388^{* *}$ & 1 & \\
\hline $\begin{array}{l}\text { Eleştirel Düşünme } \\
\text { Toplam }\end{array}$ &, $195^{* *}$ &, $182^{* *}$ &, $198^{* *}$ &, $195^{* *}$ &, $171^{* *}$ &, $770^{* *}$ &, $752^{* *}$ &, $788^{* *}$ &, $740^{* *}$ &, $730^{* *}$ &, $653^{* *}$ &, $763^{* *}$ &, $529 * *$ &, $612^{* *}$ & $608^{* *}$ & 1 \\
\hline
\end{tabular}


Ayrıca "karmaşıklık" ve "formalleşme" özellikleri örgüt sağlığının tüm boyutları ile pozitif yönde ilişkilidir. "Merkezileşme" ise örgüt sağlığı alt boyutlarından "örgütsel bütünlük", "çevresel etkileşim" ve "örgütsel ürün" alt boyutları ile negatif yönde ilişkili çıkmıştır. Buna ek olarak Taneri'ye (2011) göre ilköğretim öğretmenlerinin etik liderlik davranışları ile örgüt sağlığı arasında pozitif yönde orta düzeyde anlamlı ilişki vardır. Buluç’a (2008) göre örgütsel vatandaşlık ile akademik önem arasında yüksek bir korelasyon bulunmaktadır. Edwards'ın (2008) çalışmasında algılanan liderlik stili ile örgüt sağlığı arasında pozitif yönde bir ilişki olduğu ortaya çıkmıştır. Ayrıca örgüt sağlığının alt boyutlarından "mesleki liderlik", "kaynak etkisi" ve "akademik odak" boyutları ile algılanan liderlik stili arasında anlamlı pozitif bir ilişki tespit edilmiştir. Moses (2010) iki farklı okuldaki örgüt sağlığı ve öğretmen yeterliğini nitel ve nicel araştırma yöntemlerini kullanarak araştırmıştır. Karşılaştırmalı veriler temele alınarak elde edilen bulgulara göre, her iki okul için bulunan örgüt sağlığı ortalamanın altındadır. Nitel veriler örgüt sağlığı daha fazla olduğu belirtilen okulun lehine dikkate değer bir farklılık olduğunu göstermiştir.

Eleştirel düşünme ile farklı değişkenlerin ilişkilerini inceleyen araştırmalar incelendiğinde; Sakar’a (2015) göre öğretmen adaylarının eleştirel düşünme tutumları ile algıladıkları mesleki etik ilkeleri arasında pozitif yönde, düşük düzeyde anlamlı bir ilişki olduğu görülmektedir. Varoğlu'na (2014) göre ortaokul öğretmenlerinin eleştirel düşünme eğilimleri ile sınıf yönetimi anlayış algıları arasında pozitif yönlü ve düşük düzeyde bir ilişki bulunmaktadır. Erdem, İlğan ve Çelik'e (2013) göre duygusal zekanın tüm alt boyutları ile eleştirel düşünme eğilimleri ölçeğinin tüm alt boyutları arasında pozitif yönde anlamlı ilişkiler olduğu görülmektedir. Tuncer'e (2013) göre eleştirel düşünme eğilimi ile mantıklı karar verme stratejisi arasında pozitif yönde bir ilişki bulunmuştur. Saracaloğlu ve Yılmaz'a (2011) göre ise öğretmen adaylarının eleştirel düşünme tutumları ile denetim odağı arasında pozitif yönlü düşük bir ilişki bulunmaktadır.

$\mathrm{Bu}$ araştırmanın bulguları incelendiğinde ortaöğretim öğretmenlerinin eleştirel düşünme becerileri ile okul sağlığı algıları arasında olumlu yönde düşük düzeyde bir ilişki çıkmasının nedeni eleştirel düşünme becerilerine sahip olan öğretmenlerin oluşturduğu bir örgütün çalışma atmosferinin, 
iş standartlarının, kurum kültürünün memnun edici düzeyde olması olabilir. Eleştirel düşünme eğilimine sahip öğretmenlerin bir okulu sağlıklı kılan faktörlere katkı sağlayacağı da göz önüne alınmalıdır. Örgütte meslektaşlarına ve öğrencilerine liderlik edebilen, örgütü oluşturanlarla sosyal ilişkiler kurabilen, örgüte aidiyet hisseden, birlik ve beraberlik içinde çalışabilen, performansının karşılığını alabilen insanların eleştirel düşünme becerilerinin daha yüksek olduğu ve o örgütün de daha sağlıklı olduğu söylenebilir.

\section{Ö̆gretmenlerin eleştirel düş̧ünme becerileri okul să̆h̆̆g algılarının an- lamlı bir yordayıcısı midır?}

Bu alt problem doğrultusunda yapılan çoklu regresyon analizi sonucunda elde edilen bulgular Tablo 13'te verilmektedir. Ortaöğretim öğretmenlerinin eleştirel düşünme becerileri ile örgüt sağlığı alt boyutları arasındaki ilişki için regresyon katsayılarının anlamlılığına ilişkin $t$ testi değerleri incelendiğinde eleştirel düşünme becerileri alt boyutlarının örgütsel sağlık alt boyutları üzerinde anlamlı bir açıklayıcı olduğu görülmüştür.

Analiz sonuçlarına göre eleştirel düşünme alt boyutlarından "Bilgileri sorgulama", "Duygu, düşünce ve değerleri farkındalık" ve "Eleştirel açıl1k" alt boyutlarının örgüt sağlığı alt boyutlarından "Örgütsel liderlik" alt boyutunun yaklaşık \% 6,5'ini açıladığı görülmektedir $\left(R=0.255, R^{2}=0.065\right.$, $\mathrm{p}<0.05)$. Bu bağlamda sorgulama yeteneğine sahip, kendi duygu, düşünce ve değerlerini farkında olan ve eleştiriye açık öğretmenlerin ve yöneticilerin örgütün yönetimini, amaçlarını ve hedeflerini belirlemede, amacın ve sürecin planlanması ve kontrol edilmesinde ve eldeki kaynakların en iyi şekilde kullanılmasında etkin rol oynadığı söylenebilir. Ortaöğretim öğretmenlerinin eleştirel düşünme becerilerinin okul sağlığı algılarını anlamlı olarak yordadı̆̆ görülmektedir.

Alanyazın incelendiğinde eleştirel düşünme becerilerinin örgüt sağllğının anlamlı bir yordayıcısı olup olmadığını inceleyen bir araştırmaya rastlanmamıştır. Alanyazındaki örgüt sağlığı ile ilgili çalışmalar incelendiğinde Güçlü, Receoğlu ve Kılınç’a (2014) göre örgüt sağlığı öğretmenlerin motivasyonunun anlamlı bir yordayıcısıdır. Özdemir'e (2012) göre ise okul kültürünün "destek", "bürokratik" ve "görev" boyutları okul sağl1- 
ğının akademik boyutunu pozitif yönde ve anlamlı düzeyde yordamaktadır ayrıca okul kültürünün alt boyutlarından "destek kültürü", ögretmen moralinin tek anlamlı yordayıcısıdır. Ordu'ya (2011) göre örgütsel yapının alt boyutlarından örgütsel sağlık alt boyutlarıu üzerinde etkileri anlamlı çıkmıştır. Taneri'ye (2011) göre ise ilköğretim okullarında etik liderlik örgüt sağlığının yordayıcısıdır. Hoy ve Woolfolk'a (1993) göre ise örgüt sağlığı boyutlarından "örgütsel bütünlük" ve "moral" öğretmenlerin genel öğretim yeterliliğini yordamaktadır.

Tablo 13. Ortaöğretimde çalışan öğretmenlerin okul sağlığı algılarının yordanmasına ilişkin çoklu regresyon analizi

\begin{tabular}{|c|c|c|c|c|c|c|c|}
\hline & Değişkenler & B & SEв & $\beta$ & $\mathrm{T}$ & $\mathbf{P}$ & $\mathbf{R}^{2}$ \\
\hline \multirow{11}{*}{ 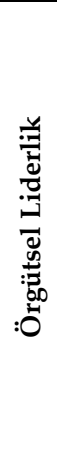 } & Sabit & 2,340 & ,331 & - & 7,087 & ,000 & \multirow{11}{*}{065} \\
\hline & Düşünceleri düzene koyma &,- 080 & 077 &,- 078 & $-1,044$ & 297 & \\
\hline & Bilgileri sorgulama &,- 188 & 088 &,- 157 & $-2,144$ & 033 & \\
\hline & $\begin{array}{l}\text { Duygu, düşünce, değerleri farkın- } \\
\text { dalık }\end{array}$ & ,278 & ,093 & ,243 & 3,001 & ,003 & \\
\hline & Problem çözme & 056 & ,067 & ,053 & 829 & 407 & \\
\hline & Açık fikirlilik ve hoşgörü & 043 & ,082 & ,034 &, 521 & 602 & \\
\hline & Eşduyum (Düşüncede esneklik) &,- 001 & 083 & ,000 &,- 006 & ,995 & \\
\hline & Kendini geliştirme &,- 056 & 081 &,- 050 &,- 685 & ,494 & \\
\hline & Eleştiriye açıklık & ,159 & 072 & ,129 & 2,207 & 028 & \\
\hline & Fikirlerde ayrıntıya dikkat &,- 017 & ,061 &,- 017 &,- 273 & 785 & \\
\hline & Akılcı düşünme & 052 & ,063 & 052 & ,830 & ,407 & \\
\hline \multirow{11}{*}{ 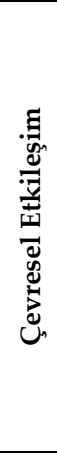 } & Sabit & 2,190 & 279 & - & 7,853 & ,000 & \multirow{11}{*}{044} \\
\hline & Düşünceleri düzene koyma &,- 029 & ,065 &,- 035 &,- 447 & 655 & \\
\hline & Bilgileri sorgulama &,- 073 & 075 &,- 073 &,- 963 & ,336 & \\
\hline & $\begin{array}{l}\text { Duygu, düşünce, değerleri } \\
\text { farkındalık }\end{array}$ & 141 & 077 & 150 & 1,839 & ,067 & \\
\hline & Problem çözme &,- 073 & 075 &,- 073 &,- 963 & ,336 & \\
\hline & Açık fikirlilik ve hoşgörü & ,008 &, 067 & ,008 & 123 & ,902 & \\
\hline & Eşduyum (Düşüncede esneklik) & 034 & 070 & ,032 & 485 & 628 & \\
\hline & Kendini geliştirme &,- 041 & ,068 &,- 045 &,- 604 & ,546 & \\
\hline & Eleştiriye açıklık & 121 & 061 & 120 & 1,996 & 047 & \\
\hline & Fikirlerde ayrıntıya dikkat &,- 006 & 051 &,- 007 &,- 118 & ,906 & \\
\hline & Akılcı düşünme & 026 & 052 & 031 & 494 & 622 & \\
\hline \multirow{7}{*}{ 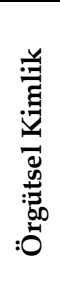 } & Sabit & 2,110 & 302 & - & 6,993 & 000 & \multirow{7}{*}{, 051} \\
\hline & Düşünceleri düzene koyma &,- 048 & ,068 &,- 053 &,- 711 & ,478 & \\
\hline & Bilgileri sorgulama &,- 028 & 077 &,- 026 &,- 365 & ,715 & \\
\hline & $\begin{array}{l}\text { Duygu, düşünce, değerleri farkın- } \\
\text { dalık }\end{array}$ & 127 & 082 & ,122 & 1,547 & 123 & \\
\hline & Problem çözme &,- 042 &, 060 &,- 045 &,- 706 & 481 & \\
\hline & Açık fikirlilik ve hoşgörü & 108 & 071 & ,094 & 1,511 & 132 & \\
\hline & Eşduyum (Düşüncede esneklik) &,- 012 & 073 &,- 010 &,- 159 & 874 & \\
\hline
\end{tabular}




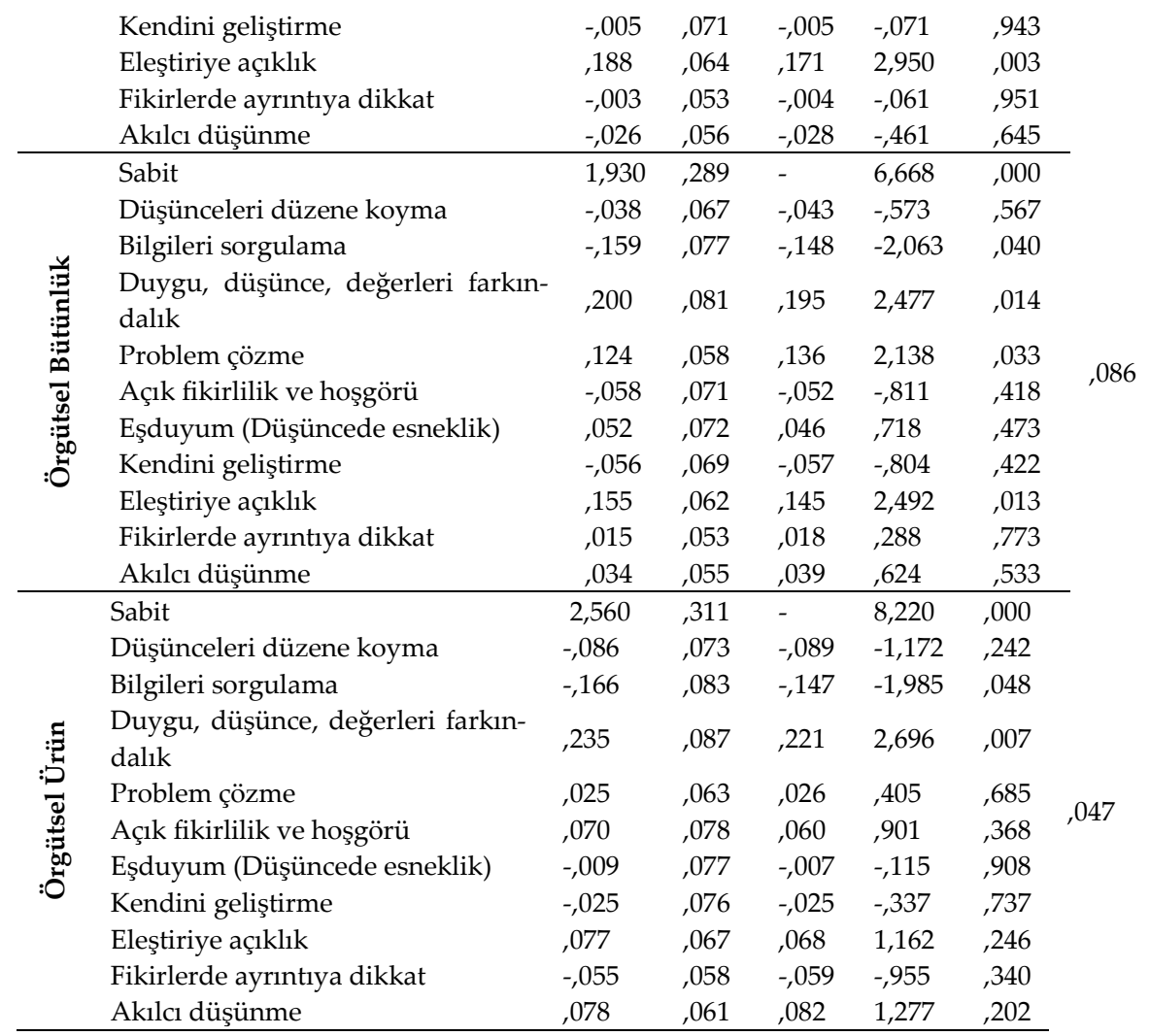

Alanyazın ve bu araştırmanın bulguları doğrultusunda ortaöğretim öğretmenlerinin "Duygu, düşünce ve değerleri farkındalık" alt boyutu puanlarının "Örgütsel liderlik", "Çevresel etkileşim", "Örgütsel bütünlük" ve "Örgütsel ürün" alt boyutları üzerinde en yüksek etkiye sahip olmasının bir nedeninin kişinin öz bilinci ve farkındalığı ile örgütün sağlığına olumlu katkı sağlaması olabilir. Diğer bir deyişle örgüte liderlik eden, sosyal ilişkileri kuvvetli, birlik ve bütünlük içerisinde çalışabilen ve örgüte ürün sunabilen kişilerin kendi duygu, düşünce ve değerlerinin farkında olan ve kendini tanıdığ 1 için de kendini nasıl geliştirebileceğini bilen kişiler oldukları söylenebilir. "Eleştiriye açıklık" alt boyutunun ise "Örgütsel kimlik" alt boyutu üzerinde en yüksek etkiye sahip olmasının ne- 
deni ise örgütte örgütle özdeşleşmiş bir kimliğe sahip olan kişilerin eleştirel becerilerini geliştirmiş bundan dolayı da eleştiriye açık kişiler olması olabilir.

\section{Sonuç ve Öneriler}

$\mathrm{Bu}$ bölümde, araştırmanın sonuçları belirtilmiş ve tekrardan kaçınmak üzere her bir sonuca dayalı varsa araştırmacı ve uygulamadakiler için önerilere yer verilmiştir.

Ortaöğretim öğretmenlerinin eleştirel düşünme becerileri toplam puanı ve "Duygu, düşünce ve değerleri farkındalık", "Açık fikirlilik ve hoşgörü", "Eşduyum (Düşüncede esneklik)", "Kendini geliştirme", "Eleştiriye açıklık" ve "Fikirlerde ayrıntıya dikkat" alt boyutlarında kadınların puan ortalamalarının erkeklerden yüksek olduğu tespit edilmiştir.

- Erkek öğretmenlerin eleştirel düşünme becerilerini geliştirmeleri için çalıştaylar, seminerler ve hizmet içi eğitimler düzenlenmelidir. Edindikleri niteliklerin maddi ve sosyal pekiştireçlerle teşvik edilmesi sağlanmalıdır. Araştırmacılar kadın ve erkek arasındaki bu farkın nedenleri ile ilgili araştırmalar yapabilirler.

- Ortaöğretim öğretmenlerinin eleştirel düşünme becerileri toplam puanları branşlarına göre anlamlı düzeyde farklılık göstermemektedir. Ancak "Açık fikirlilik ve hoşgörü" ile "Fikirlerde ayrıntıya dikkat" alt boyutlarında sözel dersleri veren öğretmenlerin ortalamalarının diğer branşlarda derse giren öğretmenlere göre daha yüksek olduğu görülmüştür.

- Düşünme becerilerinin geliştirilmesi için lisans eğitimi her branşın kendine özgü içeriği temelinde yapılmalıdır. Bunun için içerik, yöntem ve tekniklerin zenginleşmesi sağlanmalıdır. Fark çıkan ve çıkmayan özellikleri bağlamında araştırmacılar nedensel desende çalışmalar yapabilirler.

- Ortaöğretim öğretmenlerinin okul sağlığına ilişkin algılarının “örgütsel kimlik" boyutunda kadınların puan ortalamaları erkeklerin puan ortalamalarından daha yüksektir.

- Erkek öğretmenlerin en az kadınlar kadar kendilerini okula ait hissetmelerine destek olacak bir iklim ve kültür yaratılmalıdır. Öğretmenliğin bir kadın mesleği olduğuna dair algının değiştirilmesine yönelik 
girişimlerde bulunulmalıdır. Araştırmacılar özellikle öğretmenlik mesleğinin kadın mesleği haline dönüşüm nedenlerini ortaya koyacak ve bunun önüne geçilmesini sağlayacak çalışmalara yol gösterecek araştırmalar yapabilirler.

- Ortaöğretim öğretmenlerinin okul sağlığı algıları "çevresel etkileşim", "örgütsel kimlik" ve "örgütsel ürün" alt boyutlarında sözel dersleri veren öğretmenlerin puanlarl; "örgütsel bütünlük" alt boyutunda ise sayısal dersleri veren öğretmenlerin puanları diğer alanların derslerine giren öğretmenlerin puanlarından daha yüksek bulunmuştur.

- Eğitim yöneticileri ve diğer çalışanlar tarafından her branştaki öğretmenlerin sağlıklı bir okulda çalıştıklarını özümseyebilmeleri için derslerine ve kendilerine değer verildiği hissettirilmelidir. Araştırmacılar, böyle bir ortamın şekillenmesini sağlayacak projeler ve araştırmalar yapabilirler.

- Ortaöğretim öğretmenlerinin okul sağlığ1 algıları 26-50 arasında öğretmenin ve 0-300 arasında öğrencinin bulunduğu okullarda daha yüksek çıkmıştır. Ayrıca ortaöğretim öğretmenlerinin eleştirel düşünme becerileri toplam puanları ve "Duygu, düşünce ve değerleri farkındalık", "Açık fikirlilik ve hoşgörü" ve "Eleştiriye açılık" alt boyutları puanlarının 26-50 aralığında öğretmenin çalıştığı okullarda daha yüksek olduğu görülmüştür. Buna ek olarak ortaöğretim öğretmenlerinin eleştirel düşünme becerileri “Duygu, düşünce ve değerleri farkındalık" alt boyutu puanlarının 0-300 aralığında öğrencinin eğitim-öğretim gördüğü okullarda daha yüksek olduğu görülmüştür.

- Öğretmenlerin, yöneticilerin ve diğer çalışanların güvene dayalı samimi ilişkiler geliştirmeleri için okul başına düşen öğretmen sayısı; eğitim-öğretimde sürecinde problem çözme, mantık yürütme, sorgulama gibi tekniklerin kullanılması, öğretmen ve sınıf başına düşen öğrenci sayısının azaltılması sağlanmalıdır. Araştırmacılar büyük okullarda da örgüt sağlığının olumlu algılanmasını sağlayacak tasarımlar, okul geliştirme çalışmaları yapabilirler.

- Ortaöğretim öğretmenlerinin eleştirel düşünme becerileri toplam puanları ve alt boyutları puanları ile örgüt sağlığı alt boyutları arasındaki ilişkinin olumlu yönde düşük düzeyde bir ilişki olduğu tespit edilmiştir. 
- Okul sağlığının yüksek olabilmesinin anahtarlarından birinin de eleştirel düşünme olduğu bilincinde olacak eğitim yöneticileri yetiştirilmeli ve istihdam edilmelidir. Diğer yandan eleştirel düşünme ve örgüt sağlı̆̆1 değişkenlerinin farklı değişkenlerle olan ilişkisi incelenebilir. Farklı örneklem grupları ile söz konusu değişkenlerin ilişkisinin incelenmesi de alanyazına katkı sağlayabilir.

- Eleştirel düşünme becerileri alt boyutlarının örgütsel sağlık alt boyutları üzerinde anlamlı bir açıklayıcı olduğu görülmüştür. "Duygu, düşünce ve değerleri farkındalık" alt boyutu diğer eleştirel düşünme becerileri alt boyutları ile karşılaştırıldığında "Örgütsel liderlik", "Çevresel etkileşim”, “Örgütsel bütünlük” ve “Örgütsel ürün” alt boyutları üzerinde en yüksek etkiye sahiptir. Buna ek olarak "Eleştiriye açıklık" alt boyutunun ise "Örgütsel kimlik" alt boyutu üzerinde en yüksek etkiye sahip olduğu tespit edilmiştir.

- Eleştirel düşünme becerisini, örgüt sağlığını ve alt boyutlarını yordama olasılığı olan başka değişkenlerle çalışılabilir. 
EXTENDED ABSTRACT

\title{
The Relationship between Secondary Schools Teachers' Critical Thinking Skills and School Health Perceptions
}

\author{
Dilşad Bakır - Erdal Toprakçı- Esen Altunay \\ National Education Ministry, Ege University
}

The fact that schools are the starting point of the change in education makes it an issue that should be emphasized especially on how healthy schools are. For the educational system and society, it can be said that the health of schools is of vital importance because there are people at every point of the cycle of input, process and output in schools as a social system. It is also possible that education organizations can respond to the needs of the next century, but only when they are healthy. In order for the school to be healthy, individuals working in schools should also have some characteristics. Critical thinking skills come at the beginning of these features. Individuals who know how to think, who can establish cause and effect relationship, question the events and phenomena around it, appreciate science and scientific thought, have analytical thinking and problem solving skills have the ability to think critically. In these schools, a productive, creative and democratic environment will be created. In this context, the aim of the study is to examine the relationship between the critical thinking skills and school health perceptions of teachers working in secondary education and to develop suggestions in accordance with the findings.

The method of the research is relational survey. The universe of the study consists of the teachers working in the state secondary schools in İzmir in the academic year 2017-2018. The sample of the study, which was determined by using proportional cluster sampling method, consists of 897 teachers working in state secondary schools in Buca, Çiğli, Gaziemir, Karabağlar, Karşıyaka and Konak districts in İzmir. 724 teachers participated in the study. "Organizational Health Scale" was developed by Akbaba (1997). The organizational health scale consists of 53 items and five 
sub-dimensions. "Critical Thinking Scale" was developed by Derelioglu (2004). Derelioglu's critical thinking scale consists of 55 questions and 10 sub-dimensions.

$\mathrm{T}$ test and variance analysis were used to determine the difference in variables with normal distribution and Sidak test was preferred to find the source of difference. In addition, Kruskal Wallis $\mathrm{H}$ test was used for the variables not having normal distribution and Mann Whitney $U$ test was used to find the source of the difference. Correlation analysis and multiple regression analysis were conducted to determine the relationship between secondary school teachers' school health perceptions and critical thinking skills.

According to the findings of this study;

1. In the total score of the secondary school teachers' critical thinking skills and in the scores of sub-dimensions of "the awareness of feelings, thoughts and values", "open-mindedness and tolerance", "empathy", "self-development", "openness to criticism" and "attention to detail in ideas" the average score of women were higher than that of men.

2. Secondary school teachers' critical thinking skills total scores did not differ significantly according to their branches. However, the average of teachers who gave verbal lessons were higher than those of other teachers in the sub-dimensions of "open-mindedness and tolerance" and "attention to detail in ideas."

3. The mean score of women in "organizational identity" sub-dimension was higher than the average score of men.

4. The scores on the perceptions of the teachers who gave verbal lessons in secondary school were found to be higher than the scores of other teachers in the sub-dimensions of "school health", "environmental interaction", "organizational identity" and "organizational product." The scores of the teachers who gave the numerical courses were found to be higher than the scores of the teachers who entered the courses of other fields in "organizational integrity" sub-dimension.

5. Secondary school teachers' scores about school health perceptions were higher in the schools with 26-50 teachers and 0-300 students. In addition, it was seen that the total scores of the secondary school 
teachers' critical thinking skills and the sub-dimensions of "the awareness of feelings, thoughts and values", "open-mindedness and tolerance" and "openness to criticism" were higher in the schools with 2650 teachers. In addition, it was seen that the scores of "the awareness of feelings, thoughts and values" sub-dimension were higher in the schools where the students were between 0-300.

6. It was found that the relationship between the scores of organizational health sub-dimensions, the total scores of secondary school teachers' critical thinking skills and the scores of sub-dimensions was positively low.

7. The sub-dimensions of critical thinking skills were found to be meaningful explanations on organizational health sub-dimensions. The sub-dimension of "the awareness of feelings, thoughts and values" has the highest effect on "organizational leadership", "environmental interaction", "organizational integrity" and "organizational product" sub-dimensions as compared to other critical thinking skills sub-dimensions. In addition, it was found that the sub-dimension of "openness to criticism" had the highest effect on the sub-dimension of "organizational identity".

At the end of the research, the following suggestions can be given: Workshops, seminars and in-service trainings should be organized for male teachers to develop critical thinking skills. For this reason, researchers can study the causes of this difference between men and women. Undergraduate education should be done on the basis of the specific content of each branch for the development of thinking skills. In addition, researchers can work in a causal pattern in the context of variables that have a meaningful difference or not. Moreover, attempts should be made to change the perception that teaching is a female profession. Researchers can do studies in order to demonstrate the reasons for the teaching profession as a female profession. Furthermore, the number of teachers per school should be reduced in order for teachers, administrators and other employees to develop intimate relationships based on trust. In addition, the number of students per teacher and class should be reduced for the use of techniques such as problem solving, reasoning and questioning. Researchers can make designs and school development studies to ensure 
positive perception of organization health in big schools. On the other hand, the relationship between the variables of critical thinking and organizational health with different variables can be examined. Finally, an examination of the relationship between these variables on different sample groups may contribute to the literature. Critical thinking ability can be studied with other variables that are likely to predict organizational health and its sub-dimensions.

\section{Kaynakça / References}

Akbaba, S. (1997). Ortaöğretim okullarının örgüt sağllğı:Bolu İli örneği. Doktora Tezi, Ankara Üniversitesi, Ankara.

Akbaba-Altun S. (2001). Örgüt sağhlğ̆ı. Ankara: Nobel Yayın Dağıtım.

Akbıyık, C. ve Seferoğlu, S. S. (2006). Eleştirel düşünme eğilimleri ve akademik başarı. Çukurova Üniversitesi Ĕ̆itim Fakültesi Dergisi, 3(32), 90-99.

Akıl, Ü. G., (2005). Bürokrasi ve ilköğretimde örgütsel să̆llk. Yüksek Lisans Tezi. Afyon Kocatepe Üniversitesi Sosyal Bilimler Enstitüsü, Afyon.

Aliakbaria, M. ve Sadeghdaghighib A. (2012). Teachers' perception of the barriers to critical thinking. Procedia - Social and Behavioral Sciences 70, 15.

Ay, Ş. ve Akgöl, H. (2008). Eleştirel düşünme gücü ile cinsiyet, yaş ve sinıf düzeyi. Kuramsal Ĕ̈itimbilim, 1(2), 65-75.

Ayaz, E. (2012). Ilköğretim okullarındaki yöneticilerin eleştirel düşünme gücü üzerine bir araştırma:İstanbul ìli, Avrupa Yakası örneği. Yüksek Lisans Tezi. Yeditepe Üniversitesi Sosyal Bilimler Enstitüsü. İstanbul.

Aybek, B. (2006). Konu ve beceri temelli eleştirel düşünme öğretiminin öğretmen adaylarmın eleştirel düşünme eğilimi ve düzeyine etkisi. Yayınlanmamış Doktora Tezi, Çukurova Üniversitesi Sosyal Bilimler Üniversitesi, Adana.

Beşoluk, Ş. ve Önder, İ. (2010). Öğretmen Adaylarının Öğrenme Yaklaşımları, Öğrenme Stilleri ve Eleştirel Düşünme Becerilerinin İncelenmesi. İlköğretim Online, 9(2), 679-693. 26.07.2016 tarihinde http://ilkogretimonline.org.tr adresinden erişilmiştir.

Buluç, B. (2008). Ortaöğretim okullarında örgütsel sağlık ile örgütsel vatandaşlık davranışları arasındaki ilişki. Türk Egitim Bilimleri Dergisi, 6(4), 571-602. 
Choy, C. ve Cheah, P. K. (2009). Teacher perceptions of critical thinking among students and its influence on higher education. International Journal of Teaching and Learning in Higher Education, 20(2), 198-206. 26.07.2016 tarihinde http://www.isetl.org/ijtlhe/ ISSN 1812-9129 adresinden erişilmiştir.

Derelioğlu, Y. (2004). Üniversite öğrencilerinde eleştirel düşünme ile denetim odağ arasındaki ilişkinin incelenmesi. Doktora Tezi. Marmara Üniversitesi, Eğitim Bilimleri Enstitüsü, İstanbul.

Ebcim, P. Ö. (2012). Resmi ilköğretim okullarında görev yapan öğretmenlerin motivasyon düzeyleri ile örgüt sağlığı algıları arasındaki ilişki. Yüksek Lisans Tezi. Maltepe Üniversitesi, Sosyal Bilimler Enstitüsü, İstanbul.

Edwards, C. B. (2008) An investigation of the relationship between transformational leadership and organizational health. Unpublished Doctoral Dissertation. Capella University, Minneapolis.

Erdem, M. İlğan, A. ve Çelik, F. (2013). Lise öğretmenlerinin duygusal zeka düzeyleri ile eleştirel düşünme becerileri arasındaki ilişki. Turkish Studies-International Periodical For the Languages, Literature and History of Turkish or Turkic, 8(12), 509-532.

Eskicumalı, A., Yaman, E., Yaman, H. (2014). Öğretmenlik mesleğinin sosyoekonomik statüsü. bu mesleğin bir bayan mesleği haline dönüşmesi durumu ve eğitim fakültesi üzerine bir araştırma. Sakarya Üniversitesi Eğitim Fakültesi Dergisi, (2), 53-68.

Güçlü, N., Recepoğlu, E. ve Kılınç, A. Ç. (2014). İlköğretim okullarının örgütsel sağlığı ile öğretmenlerin iş motivasyonları arasındaki ilişki. Hacettepe Üniversitesi Ĕ̆itim Fakültesi Dergisi, 29(1), 140-156.

Gürkan, F. B. (2006). Illköğretim okullarının örgütsel sağllk düzeyi:Polatl İlçesi örneği. Yüksek Lisans Tezi. Gazi Üniversitesi Eğitim Bilimleri Enstitüsü. Ankara.

Hoy, C. J. Tarter ve R. B. Kottkamp. (1991). Open schools / Healty schools. Sage Publications.

Hoy, W. K. ve Woolfolk, A. (1993). Teachers' sense of efficacy and the organizational health of schools. The elementary school journal, 93(4), 355-372.

Kesik, F. ve Balcı, E. (2015). Avrupa birliği projelerine katılım gösteren okulların sağlığına ilişkin öğretmen algıları. Abant İzzet Baysal Üniversitesi Eğitim Fakültesi Dergisi, 15(2), 163-183.

Korkmaz, Ö. (2009a). Öğretmenlerin eleştirel düşünme eğilim ve düzeyleri. Türk Ĕ̆itim Bilimleri Dergisi, 7(4), 879-90. 
Korkmaz, Ö. (2009b). Eğitim fakültelerinin öğrencilerin eleştirel düşünme eğilim ve düzeylerine etkisi. Ahi Evran Üniversitesi Kırşehir Ĕ̆itim Fakültesi Dergisi (KEFAD) 10(1), 1-13.

Moses, N. A. E. (2010) Organizational health and teacher efficacy: A qualitative analysis of two measures in elementary schools. Unpublished Doctoral Dissertation. Alfred University, New York.

Olgun, İ. (2012). İlköğretim okul yöneticilerinin okul sağlığına etkisinin çeşitli değişkenler açısından incelenmesi:Kahramanmaraş İli Merkez İlçe örneği. Yüksek Lisans Tezi. Yeditepe Üniversitesi, Sosyal Bilimler Enstitüsü, İstanbul.

Ordu, A. (2011). İlköğretim okullarında örgütsel yapı ile örgüt sağllğı arasındaki ilişkiler. Doktora Tezi. Pamukkale Üniversitesi. Sosyal Bilimler Enstitüsü.

Özdemir, S. (2012). İlköğretim okullarında okul kültürü ile örgütsel sağllk arasindaki ilişki. Kuram ve Uygulamada Ĕ̆itim Yönetimi, 18(4), 599-620.

Palavan, Ö. Gemalmaz, N. ve Kurtoğlu, D. (2015). Sınıf öğretmenlerinin eleştirel düşünme becerisine ve eleştirel düşünme becerisinin geliştirilmesine yönelik görüşleri. Mustafa Kemal Üniversitesi Sosyal Bilimler Enstitüsü Dergisi, 12(30), 26-49.

Recepoğlu, E. ve Özdemir, S. (2014). Türkiye'deki öğretmenlerin ilköğretim okullarının örgüt sağlığına ilişkin algılarının incelenmesi. Cumhuriyet International Journal of Education-CIJE, 3(1), 34-58. e-ISSN: 2147-1606

Sağlam, M., L. Vural ve A. Adıgüzel. (2007). Yeni ilköğretim programının uygulanması sürecinde önceki programa göre istenmeyen öğrenci davranışlarının görülme sıklığı. VI. Ulusal Sınıf Öğretmenliği Sempozyumu, 27-29 Nisan 2007, Eskişehir.

Sakar, N. (2015). Öğretmen adaylarının eleştirel düşünme tutumları ile algıladıkları mesleki etik ilkelerin incelenmesi. Yüksek Lisans Tezi. Çukurova Üniversitesi Sosyal Bilimler Enstitüsü. Adana.

Saracaloğlu, A. S. ve Yılmaz, S. (2011). Öğretmen adaylarının eleştirel düşünme tutumları ile denetim odaklarının incelenmesi. İlköğretim Online, 10(2), 468-478. 29.04.2016 tarihinde http://ilkogretim-online.org.tr adresinden erişilmiştir.

Şengül, C. ve Üstündağ, T. (2009). Fizik öğretmenlerinin eleştirel düşünme eğilimi düzeyleri ve düzenledikleri etkinliklerde eleştirel düşünmenin yeri. Hacettepe Üniversitesi Ĕ̆itim Fakültesi Dergisi, 36, 237-248.

Şişman, M. (2002). Örgütler ve kültürler. Ankara: PegemA Yayınc1lık. 
Şişman, M. ve Taşdemir, İ. (2008). Türk eğitim sistemi. Ankara: Pegem Akademi.

Taneri, A. (2011). İlköğretim okullarında etik liderlik ile örgüt sağlığı arasındaki ilişki:Aksaray İli örneği. Yüksek Lisans Tezi. Gazi Üniversitesi, Eğitim Bilimleri Enstitüsü, Ankara.

Toprakçı, E. (2013). Sinıf yönetimi. Ankara: Pegem Akademi.

Tsui, K. T. ve Cheng, Y. C. (1999). School organizational health and teacher commitment: a contingency study with multi-level analysis. An International Journal on Theory and Practice, 5(3), 249-268.

Tuncer, M. A. (2013). Okul yöneticilerinin eleştirel düşünme eğilimleri ile karar verme stratejileri arasındaki ilişki:İstanbul İli Maltepe İlçesi örneği. Yüksek Lisans Tezi. Yeditepe Üniversitesi, Sosyal Bilimler Enstitüsü. İstanbul.

Varoğlu, G. (2014). Öğretmenlerin sını yönetimi anlayışlar ile eleştirel düşünme eğilimleri arasındaki ilişkinin incelenmesi:İstanbul ìli, Beşiktaş İlçesi örneğgi. Yüksek Lisans Tezi. Yeditepe Üniversitesi, Eğitim Bilimleri Enstitüsü, İstanbul.

Yıldız, Ç. (2014). Okul yöneticilerinin kriz yönetim tutumlar ile algılanan örgüt sağlı̆̆ı arasındaki ilişki:Üsküdar İlçesi örneği. Yüksek Lisans Tezi. Yeditepe Üniversitesi Sosyal Bilimler Enstitüsü. İstanbul.

Yurdakul, B. (2008). Yapılandırmacı öğrenme yaklaşımının sosyal bilişsel bağlamda bilgiyi oluşturmaya katkısı. Balıkesir Üniversitesi, Sosyal Bilimler Enstitüsü Dergisi, 11(20), 39-67.

\section{Kaynakça Bilgisi / Citation Information}

Bakır, D., Toprakçı, E. ve Altunay, E (2019). Ortaöğretimde çalışan öğretmenlerin eleştirel düşünme becerileri ile okul sağlığı algıları arasındaki ilişki. OPUS-Uluslararası Toplum Araştırmaları Dergisi, 13(19), 223-262. DOI: 10.26466-/opus.569567 